\title{
Metabolites from Marine Microorganisms, Micro, and Macroalgae: Immense Scope for Pharmacology
}

\author{
Noora Barzkar ${ }^{1, *}$ (D) Saeid Tamadoni Jahromi ${ }^{2, *}$, Hadi Bolooki Poorsaheli ${ }^{3,4}$ and Fabio Vianello ${ }^{5}$ \\ 1 Department of Marine Biology, Faculty of Marine Science and Technology, University of Hormozgan, \\ Bandar Abbas 74576, Iran \\ 2 Persian Gulf and Oman Sea Ecology Research Center, Iranian Fisheries Sciences Research Institute, \\ Agricultural Research Education and Extension Organization (AREEO), Bandar Abbas 93165, Iran \\ 3 Road, Housing \& Urban Development Research Center (BHRC), Persian Gulf Branch, \\ Bandar Abbas 93144, Iran \\ 4 Department of Engineering, Islamic Azad University, Bandar Abbas 1696, Iran \\ 5 Department of Comparative Biomedicine and Food Science, University of Padua, viale dell'Università 16, \\ Legnaro 35020, Italy \\ * Correspondence: noora.barzkar@gmail.com or barzkar.phd@hormozgan.ac.ir (N.B); \\ stamadoni@gmail.com (S.T.J.)
}

Received: 16 June 2019; Accepted: 27 July 2019; Published: 8 August 2019

\begin{abstract}
Marine organisms produce a large array of natural products with relevance in drug discovery. These compounds have biological activities such as antioxidant, antibacterial, antitumor, antivirus, anticoagulant, anti-inflammatory, antihypertensive, antidiabetic, and so forth. Consequently, several of the metabolites have made it to the advanced stages of clinical trials, and a few of them are commercially available. In this review, novel information on natural products isolated from marine microorganisms, microalgae, and macroalgae are presented. Given due research impetus, these marine metabolites might emerge as a new wave of promising drugs.
\end{abstract}

Keywords: marine microorganisms; natural products; pharmaceutical potential; bacteria; microalgae; macroalgae

\section{Introduction}

Oceans cover about $70 \%$ of the earth's surface, serving as the habitat of a great diversity of organisms [1]. These organisms produce numerous metabolic products. Especially, lower organisms elaborate a multitude of secondary metabolites as signaling molecules for "defense and offense". These compounds, which belong to diverse chemical classes, can act as potential therapeutics for healthcare [2]. In the past decades, several promising therapeutics have been extracted from bacteria, fungi, corals, micro- and macroalgae, gorgonians, sponges, nudibranchs, bryozoans, sea cucumbers, tunicates, and sea hares, among other marine organisms [3]. Considerable efforts have been directed towards the isolation of these compounds, and at the moment, more than 10,000 natural products (NPs) of potential biotechnological interest have been isolated [4]. The present review reports on the most promising bioactive compounds of marine origin, emphasizing their pharmaceutical potential.

\section{Bioactive NPs from Marine Bacteria and Fungi}

In the marine environment, bacteria and fungi are pervasive. In the past decades, the number of reported bioactive compounds derived from marine bacteria and fungi has steadily increased [5]. Marine bacteria produce a large repertoire of secondary metabolites to survive in the hostile oceanic conditions. Among others, thermophilic and archaea bacteria elaborate thermostable enzymes which belong to diverse classes $[1,6]$. 


\subsection{Antibiotic Activity}

The myxomycetes Lycogala epidendrum produces halogenated bisindole pyrrole derivatives (Lynamicins A-E) (Figure 1A-D) with antibacterial activity against Enterococcus faecalis, Staphylococcus epidermidis, and Staphylococcus aureus. Efficacy against these pathogens suggests the potential application of these compounds for the treatment of nosocomial infections [7]. Similarly, a bacterium isolated from the sea grass Thalassia produces a highly brominated pyrrole antibiotic [8]. The crude extract of Nocardia sp. strain, isolated from the marine red marine alga Laurenica spectabilis, produces active compounds against bacterial and fungal pathogens [9]. The eggs of the oriental shrimp Palaemon macrodactylus harbor bacterial epibionts with antifungal potential towards the pathogenic fungus Lagenidium callinectes [10]. Likewise, marine fungi have been studied for their bioactive compounds and they have proven to be a valuable source of antibacterial, antibiotic, antifungal, and anticancer compounds [11]. A marine Aspergillus sp. fungus was isolated from the large marine brown alga Sargassum horneri, and it produces a polyoxygenated decalin, dehydroxychlorofusarielin B (Figure 1E), which has demonstrated antibacterial activity against methicillin-resistant and multidrug-resistant (MDR) S. aureus [12]. Another fungal Aspergillus sp. strain, isolated from a sea fan (Alcyonacea), was found to produce antibacterial compounds against S. aureus ATCC 25923 and methicillin-resistant S. aureus [13].
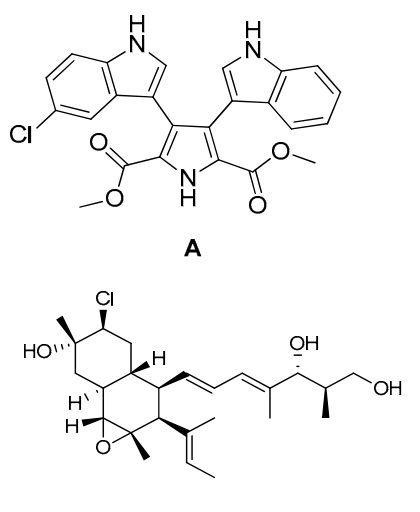

E<smiles>CCCCCc1cc(=O)c2c(CC(=O)OC)cc(O)cc2o1</smiles>

H

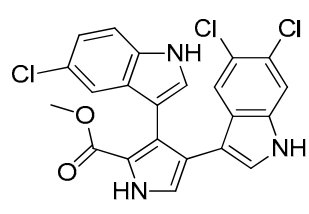

B

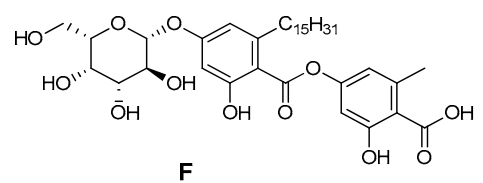

F

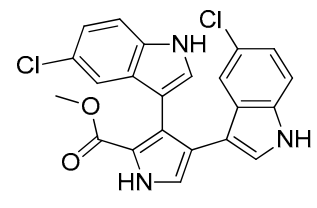

C

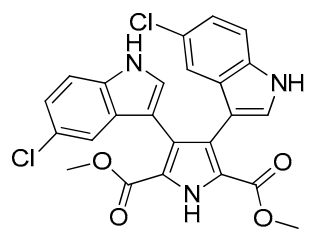

D

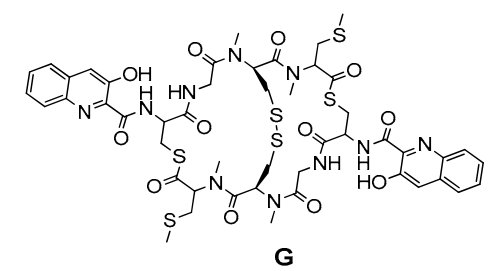

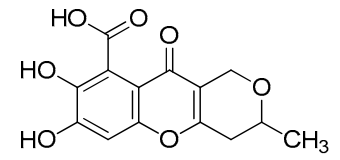

I<smiles></smiles>

J

Figure 1. Chemical structure of marine natural compounds isolated from marine microorganisms. (A) Lynamicin E; (B) Lynamicin B; (C) Lynamicin A; (D) Lynamicin D; (E) Dehydroxychlorofusarielin B; (F) Aquastatin A; (G) Thiocoraline; (H) Pestalotiopsone F; (I) Anhydrofulvic acid; (J) Citromycetin.

\subsection{Anticancer Activity}

Besides antibiotics, marine microorganisms are also a source of anticancer principles. The bacterium Micromonospora sp. produces thiocoraline (Figure 1G), a depsipeptide which inhibits cellular DNA polymerase- $\alpha$. This substance has been applied for the treatment of cancer in preclinical research [14]. An unidentified fungus of the Pleosporales order (strain CRIF2) produces several compounds showing weak cytotoxic activity against tumor cell lines [15]. A Pestalotiopsis sp. fungus, isolated from the leaves of Rhizophora mucronata, produces a chromone, namely, pestalotiopsone $\mathrm{F}$ (Figure 1H), which displays cytotoxic activity against L5178Y murine cancer cells [16]. 


\subsection{Antidiabetic Activity}

Diabetes mellitus (or diabetes) is a debilitating and often life-threatening disorder that is prevalent worldwide, and the number of patients is significantly increasing [17]. Marine fungi have been screened for possible antidiabetic compounds [18]. The Cosmospora sp. SF-5060 fungus produces aquastatin A (Figure 1F), a secondary metabolite which inhibits protein tyrosine phosphatases 1B (PTP1B) with an effective concentration $\left(\mathrm{EC}_{50}\right)$ value of $0.19 \mu \mathrm{M}$. As PTP1B regulates insulin signaling and leptin receptor, aquastatin A might find an application in diabetes management [18]. Another marine fungus, Penicillium sp. JF-55, produces methylethylketone, which exerts inhibitory action on PTP1B as well. Other substances obtained from marine fungi are penstyrylpyrone, anhydrofulvic acid (Figure 1I), and citromycetin (Figure 1J), all displaying inhibitory actions of PTP1B with $\mathrm{IC}_{50}$ values in the micromolar range [19].

Generally, marine bacteria and fungi species survive under hostile conditions, for example, high shear stress, high salinity, high light intensity, and low temperatures, which result in the elaboration of a large array of fascinating and structurally complex molecules. In Table 1, some of the bioactive compounds produced by marine fungi and bacteria are listed. 
Table 1. Structure and biological activity of some novel marine microorganisms' natural compounds.

\begin{tabular}{|c|c|c|c|c|c|}
\hline \multicolumn{6}{|c|}{ Marine Microorganisms (Bacteria, Fungi, and Cyanobacteria) } \\
\hline Compound & Chemical Structure & Source/Species & Biological Activity & Mechanism of Action & References \\
\hline Salinosporamide A & & $\begin{array}{l}\text { Actinomycete/ } \\
\text { Salinispora tropica }\end{array}$ & $\begin{array}{l}\text { Treatment of multiple } \\
\text { myeloma (anticancer); } \\
\text { antimalarial }\end{array}$ & $\begin{array}{l}\text { Inhibits proteasome activity by } \\
\text { covalently modifying the threonine } \\
\text { residue of the active site of the } \\
20 S \text { proteasome }\end{array}$ & [20] \\
\hline Plinabulin & & Fungi/Aspergillus sp. & $\begin{array}{l}\text { Treatment of solid tumors } \\
\text { and lymphomas }\end{array}$ & $\begin{array}{l}\text { Depolymerizes microtubules in A549 } \\
\text { human lung carcinoma cells }\end{array}$ & [21] \\
\hline Alternaramide & & $\begin{array}{c}\text { Ascomycete } \\
\text { fungi/Alternaria sp. }\end{array}$ & Anti-inflammatory & $\begin{array}{l}\text { Inhibits inflammatory mediator } \\
\text { expression through } \\
\text { TLR4-MyD88-mediated inhibition of } \\
\text { NF-kB and MAPK pathway signaling in } \\
\text { lipopolysaccharide-stimulated } \\
\text { RAW264.7 and BV2 cells }\end{array}$ & [22] \\
\hline Macrolactin S & & Bacterium/Bacillus sp. & Antibacterial & FabG inhibition agent & [23] \\
\hline Oxaline & & $\begin{array}{c}\text { Ascomycete } \\
\text { fungi/Penicillium sp. }\end{array}$ & Antitumor & $\begin{array}{l}\text { Inhibits cell proliferation and induces } \\
\text { cell cycle arrest at the } \mathrm{G}_{2} / \mathrm{M} \text { phase in } \\
\text { Jurkat cells }\end{array}$ & [24] \\
\hline
\end{tabular}


Table 1. Cont

\begin{tabular}{|c|c|c|c|c|c|}
\hline \multicolumn{6}{|c|}{ Marine Microorganisms (Bacteria, Fungi, and Cyanobacteria) } \\
\hline Compound & Chemical Structure & Source/Species & Biological Activity & Mechanism of Action & References \\
\hline Grassystatin C & & $\begin{array}{l}\text { Tropical cyanobacteria/ } \\
\text { Okeania lorea }\end{array}$ & Cathepsin inhibition & $\begin{array}{l}\text { Potent cathepsin E inhibitor that reduces } \\
\text { antigen presentation }\end{array}$ & [25] \\
\hline Palmyramide A & & $\begin{array}{l}\text { Filamentous } \\
\text { cyanobacteria/ } \\
\text { Moorea producens }\end{array}$ & Antitumor & $\begin{array}{l}\text { Sodium channel blocking activity in } \\
\text { neuro-2a cells and cytotoxic activity in } \\
\text { H- } 460 \text { human lung carcinoma cells }\end{array}$ & [26] \\
\hline Coibamide A & & $\begin{array}{l}\text { Pantropical cyanobacteria/ } \\
\text { Caldora penicillata }\end{array}$ & Antitumor cytotoxicity & $\begin{array}{l}\text { Inhibits VEGFA/VEGFR2 expression and } \\
\text { suppresses tumor growth in } \\
\text { glioblastoma xenografts }\end{array}$ & {$[27,28]$} \\
\hline
\end{tabular}


Table 1. Cont.

Compound




\section{Metabolites with Potential Beneficial Activities from Marine Algae}

Marine algae are the primary producers of oxygen in the aquatic environment and sit at the bottom of the marine food chain, serving all other organisms [31]. Marine algae can be divided into two main groups: macroalgae (seaweeds) and microalgae, both being prolific sources of bioactive substances [32]. Therefore, research is in progress for evaluating their medicinal prospects.

\subsection{Marine Microalgae: Blue-Green Algae (Cyanobacteria)}

Marine microalgae typically constitute the phytoplanktons. They can be categorized into three groups: blue-green algae (Cyanobacteria), diatoms (Bacillariophyta), and dinoflagellates (Dinophyceae). There are over 50,000 different species of microalgae, of which only a few have been characterized [18]. Significant biochemical differences have been found among marine microalgae, resulting in a broad spectrum of novel bioactive compounds [33] of pharmaceutical interest [34]. Some of them show high antiviral and anti-HIV activity [35,36]. Recently, a new natural anti-AIDS drug has been derived from Lyngbya lagerhaimanii and Phormidium tenue (Table 2). Calcium spirulan isolated from Spirulina platensis possesses strong antiviral activity [37]. Some cyanobacteria strains produce antifouling compounds with antibiotic activity [38]. For example, the extracts of Lyngbya majuscule have been tested as a potential source of antifouling agents [39]. Some of the cyanobacteria-derived products have multiple properties. For example, ulithiacyclamide and patellamides $\mathrm{A}$ and $\mathrm{C}$ are known for their antimalarial, antitumor, and MDR-reversing activities [40]. Two new bioactive compounds, dolastatin 13 (Figure 3C) and lyngbyastatins 5-7 (Figure 3D), were isolated from Lyngbya spp., which inhibited elastase from porcine pancreas, with an $\mathrm{IC}_{50}=3-10 \mathrm{nM}$ [41]. Of the three abovementioned groups, cyanobacteria have been credited with the most bioactive compounds. Cyanobacteria (Cyanophyta) are a group of Gram-negative bacteria and one of the richest sources of novel bioactive compounds with antifungal, anti-inflammatory, antibiotic, and antitumor activities (Table 1), which make them interesting candidates for the production of molecules for new potential pharmaceutical applications [42].

\subsubsection{Antibiotic Activity}

The antibacterial activity of cyanobacteria might make them useful antibiotics sources. For example, the extracts of Anabaena variabilis and Synechococcus elongates inhibit the growth of Escherichia coli, Enterococcus, and Klebsiella [43]. The extracts of Synechocystis sp. and Synechococcus sp. showed significant antimicrobial activity towards Gram-positive bacteria [44]. Noscomin (Figure 2C), a diterpenoid, was isolated from Nostoc commune and possesses good antibacterial properties [45]. Other antibiotics are malyngamides (malyngamide $\mathrm{D}$ and malyngamide $\mathrm{D}$ acetate) and amides of the fatty acid (8)-7(S)-methoxytetradec-4(E)-enoate, isolated from the L. majuscule [46]. Analogously, ambiguine $\mathrm{H}$ isonitrile (Figure $2 \mathrm{~B}$ ) and ambiguine I isonitrile are antibiotic alkaloids purified from Fischerella sp. [47]. Another example of an antibacterial compound is kawaguchipeptin B, isolated from the toxin-producing cyanobacterium Microcystis aeruginosa [48]. 
<smiles>COc1ccc(CC(NC(=O)/C=C/CC(OC(=O)C(CC(C)C)OC(=O)[C@H](C)CNC(=O)[C@H](C)C2O[C@H]2c2ccccc2)C(C)C)C(=O)O)cc1Cl</smiles>

A

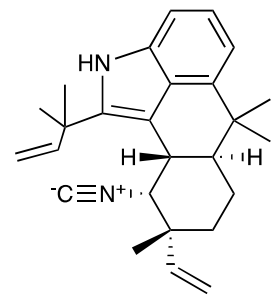

B

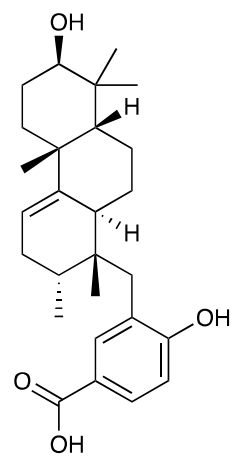

C

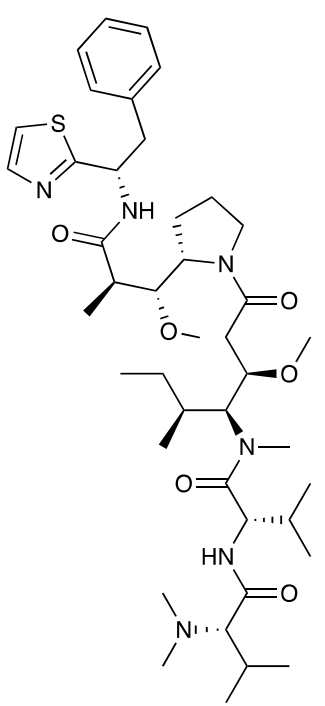

D

Figure 2. Chemical Structure of marine natural compounds isolated from marine microalgae. (A) Cryptophycin; (B) Ambiguine H isonitriles; (C) Noscomin; (D) Dolastatin 10.

\subsubsection{Antitumor Activity}

Antitumor compounds affecting cell signaling by the activation of the protein kinase $C$ cascade have been demonstrated in cyanobacteria [49]. Cyanobacteria elaborate anticancer compounds, such as dolastatin 10 (Figure 2D), curacin A, and cryptophycin (Figure 2A), which target tubulin or actin filaments of eukaryotic cells. Dolastatin 10, a strong microtubule inhibitor that can arrest cell mitotic division, was isolated from Symploca sp. [50]. Curacin A was isolated from L. majuscule and is a strong antiproliferative agent, inhibiting microtubule assembly [51]. Cryptophycin was isolated from marine Nostoc sp. GSV 224 and is an anticancer drug candidate with efficacy against L1210 leukemia cells, ovarian carcinoma cells, and drug-resistant breast cancer cells [52]. The mechanism of action of cryptophycin involves binding at the microtubule ends, leading to the disruption of cell mitosis [53]. Odoamide is a newly discovered cyclic depsipeptide from Okeanis sp., showing strong cytotoxicity against HeLa S3 human cervical cancer cells $\left(\mathrm{IC}_{50}=26.3 \mathrm{nM}\right)$ [54]. Hierridin B from Cyanobium sp. LEGE 06113 exerted cytotoxicity towards HT-29 colon adenocarcinoma cells [55].

\subsubsection{Antifungal Activity}

Cyanobacteria are important producers of antifungal substances as well, as they are competitors and predators of parasitic fungi. Many antifungal compounds have been isolated from marine extracts of cyanobacteria, including hapalindoles, tolytoxin (Figure 3A), 7-OMe-scytophycin-B, toyocamycin (Figure 3B), tijpanazole D (Figure 3G), hassallidin A, nostocyclamide, and nostodione A (Figure 3F) [56]. 7-OMe-scytophycin-B, a metabolite isolated from marine Anabaena sp. HAN21/1, has shown activity against Aspergillus flavus and Candida albicans [57]. A new antifungal lactone compound, majusculoic acid (Figure 3E), has been isolated from a marine cyanobacterial mat community. Majusculoic acid displayed antifungal activity towards C. albicans ATCC 14503 [58]. The butanol extracts of Spirulina sp. exhibited antifungal activity against Candida glabrata [59]. 


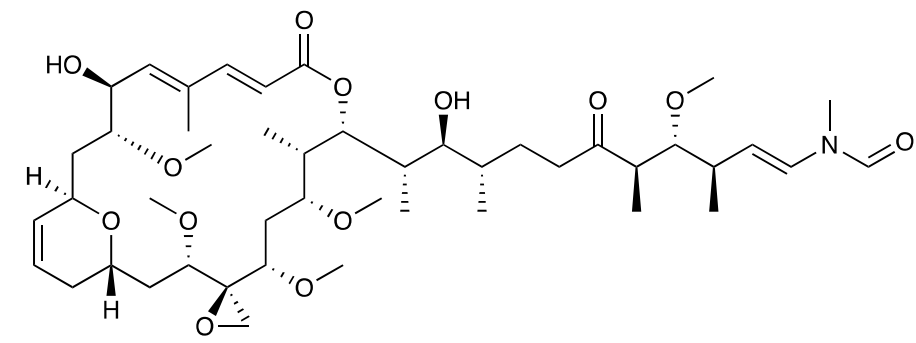<smiles>N#Cc1cn([C@@H]2O[C@H](CO)[C@@H](O)[C@H]2O)c2ncnc(N)c12</smiles>

A<smiles>C/C=C(\NC(=O)C(NC(=O)C(NC(=O)C(CO)OC)C(C)C)C(C)OC(=O)C(NC(=O)C(Cc1ccccc1)N(C)C(=O)C(Cc1ccccc1)N1C(=O)C(NC(=O)C(CO)OC)CCC1O)C(C)C)C(=O)NC(Cc1ccccc1)C(C)C</smiles>

C<smiles>CCC/C(Br)=C/C=C/CC[C@H]1C[C@H]1CCC(=O)O</smiles>

E

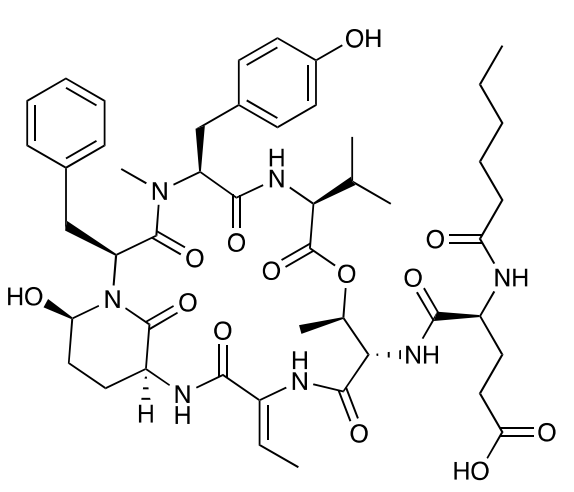

D<smiles>O=C1C(=O)c2c([nH]c3ccccc23)/C1=C/c1ccc(O)cc1</smiles>

$\mathbf{F}$<smiles>Clc1ccc2[nH]c3c(ccc4c(ccc(Cl)cc43)N2)c1</smiles>

G

Figure 3. Chemical Structure of marine natural compounds isolated from marine microalgae. (A) Tolytoxin; (B) Toyocamycin; (C) Dolastatin 13; (D) Lyngbyastatin 7; (E) Majusculoic acid; (F) Nostodione A.; (G) Tjipanazole D.

\subsubsection{Antimalarial Activity}

Antimalarial activity of natural products isolated from cyanobacteria has been reported. Gademann and Kobylinska (2009) isolated an acyl proline derivative, tumonoic acid I, from Blennothrix cantharidosmum, which exhibited moderate toxic activity against Plasmodium falciparum $\left(\mathrm{IC}_{50}=2 \mu \mathrm{M}\right)[60]$. Two new antimalarial depsipeptides, companeramides A and B, have been extracted from a marine Panamanian cyanobacteria assemblage [61]. Oscillatoria nigro-viridis produces two new linear peptides, viridamides $A$ and $B$, with antitrypanosomal and antileishmanial activity [62]. Moreover, cyanobacteria are sources of vitamins B and E [63]. Pigments extracted from cyanobacteria, such as carotenoids and phycobiliproteins, are already industrially applied as food coloring additives, as supplements for health and fertility of dairy cattle, and in the cosmetics industry. 


\subsubsection{Anti-inflammatory Activity}

Cyanobacteria metabolites have also shown pronounced anti-inflammatory effects. For instance, bis-bromoindoles from Rivularia sp. displayed powerful anti-inflammatory activity [8]. An antiinflammatory compound malyngamide $\mathrm{F}$ acetate has been derived from L. majuscule. This substance inhibited the production of nitric oxide (NO) in stimulated RAW 264.9 cells [64] by blocking the MyD88 inflammation pathway.

\subsection{Marine Macroalgae}

Macroalgae, or seaweeds, are found in intertidal regions and tropical waters. They are multicellular organisms with various arrays of morphological types and sizes and can be further classified by their photosynthetic pigments into red algae (Rhodophyceae), green algae (Chlorophyceae), and brown algae (Phaeophyceae) [65]. Currently, over 3200 novel products have been extracted from macroalgae, the majority of which come from subtropical and tropical waters [66]. Compounds with medical applications, such as antitumor, antioxidant, antiviral, antifouling, anticoagulant, antibacterial, antifungal, and anthelminthic activities, have been detected in macroalgae $[67,68]$. Red seaweeds are proposed as anticoagulants, anthelmintic, and in the treatments of gastritis and diarrhea [69]. The traditional medical uses of green seaweed spans form anthelmintic to astringent and anti-gout. Brown seaweeds are applied to cure rheumatic diseases, hypertension, arteriosclerosis, menstrual disorders, skin diseases, gastric ulcers, goiter, and syphilis and are also used as anticoagulants. Polysaccharides, such as ulvans from green seaweeds, alginates, fucans, laminarin from brown seaweeds, and carrageenans and porphyrans from red seaweeds, can stimulate defense responses against plant pathogens [70]. Thus, marine algae yield a large diversity of bioactive metabolites and appear to be a potential resource of interesting pharmacological substances. The sections below present the therapeutic compounds and functions of members from each of the three groups of seaweeds. 
Table 2. Structure and biological activity of some novel marine seaweeds' natural compounds.

\begin{tabular}{|c|c|c|c|c|c|}
\hline $\begin{array}{l}\text { Natural } \\
\text { Compound }\end{array}$ & Chemical Structure & Species & $\begin{array}{c}\text { Biological } \\
\text { Activity }\end{array}$ & Mechanism of action & References \\
\hline $\begin{array}{l}\text { Sulfated } \\
\text { galactan }\end{array}$ & & $\begin{array}{l}\text { Green alga/ } \\
\text { Codium fragile }\end{array}$ & $\begin{array}{l}\text { Immunostimulating } \\
\text { effects via } \\
\text { activation of } \\
\text { macrophages }\end{array}$ & $\begin{array}{l}\text { Stimulates the production of } \\
\text { nitric oxide by inducing iNOS at } \\
\text { mRNA and protein levels and } \\
\text { induces the expression of several } \\
\text { cytokine mRNA, such as IL-1 } \beta \text {, } \\
\text { IL-6, IL-10, and TNF- } \alpha\end{array}$ & [71] \\
\hline Caulerpin & & $\begin{array}{c}\text { Green alga/ } \\
\text { Caulerpa racemosa }\end{array}$ & $\begin{array}{l}\text { Anti-inflammatory } \\
\text { and } \\
\text { antinociceptive }\end{array}$ & $\begin{array}{l}\text { Inhibits capsaicin-induced ear } \\
\text { edema model and significantly } \\
\text { reduces the number of } \\
\text { recruited cells }\end{array}$ & [72] \\
\hline Pheophytin A & & $\begin{array}{c}\text { Green alga/ } \\
\text { Enteromorpha prolifera }\end{array}$ & Anti-inflammatory & $\begin{array}{l}\text { Exhibits significant suppression } \\
\text { of TPA-induced inflammatory } \\
\text { reaction, such as edema } \\
\text { formation in BALB/c mouse ear }\end{array}$ & [73] \\
\hline Cymopols & & $\begin{array}{c}\text { Green alga/ } \\
\text { Cymopolia barbata }\end{array}$ & Antimutagenic & $\begin{array}{l}\text { Inhibits the mutagenicity of } \\
\text { 2-aminoanthracene in T-98 strain. } \\
\text { Behaves as a metabolic activator }\end{array}$ & [74] \\
\hline
\end{tabular}


Table 2. Cont.

\begin{tabular}{|c|c|c|c|c|c|}
\hline $\begin{array}{c}\text { Natural } \\
\text { Compound }\end{array}$ & Chemical Structure & Species & $\begin{array}{c}\text { Biological } \\
\text { Activity }\end{array}$ & Mechanism of action & References \\
\hline Caulerpenyne & & $\begin{array}{c}\text { Green alga/ } \\
\text { Caulerpa taxifolia }\end{array}$ & Anticancer & $\begin{array}{c}\text { Shows cytotoxicity in cultured } \\
\text { cell lines, such as KB cells and } \\
\text { hamster fibroblasts }\end{array}$ & {$[75,76]$} \\
\hline Fucoxanthin & & Brown algae & $\begin{array}{l}\text { Antidiabetic and } \\
\text { antiobesity }\end{array}$ & $\begin{array}{l}\text { Suppresses McP-1, promotes } \\
\text { adrb3 and gluT4 expression, and } \\
\text { induces uncoupling protein } 1 \\
\text { expression in white adipose } \\
\text { tissue (WAT) mitochondria, } \\
\text { leading to oxidation of fatty acids } \\
\text { and heat production in WAT }\end{array}$ & [77] \\
\hline Dieckol & $\mathrm{OH}$ & $\begin{array}{l}\text { Brown alga/ } \\
\text { Ecklonia cava }\end{array}$ & $\begin{array}{l}\text { Anti-inflammatory } \\
\text { and } \\
\text { neuroprotective } \\
\text { agent }\end{array}$ & $\begin{array}{c}\text { Suppresses LPS-induced } \\
\text { production of nitric oxide }(\mathrm{NO}) \\
\text { and prostaglandin } \mathrm{E}_{2}\left(\mathrm{PGE}_{2}\right) \text { and } \\
\text { the expression of inducible nitric } \\
\text { oxide synthase (iNOS) and } \\
\text { cyclooxygenase-2 (COX-2) in } \\
\text { murine BV2 microglia }\end{array}$ & [78] \\
\hline Spiralisone A & & $\begin{array}{l}\text { Brown alga/ } \\
\text { Zonaria spiralis }\end{array}$ & $\begin{array}{l}\text { Kinase inhibitor } \\
\text { and antibacterial }\end{array}$ & $\begin{array}{l}\text { Shows inhibitory activity against } \\
\text { neurodegenerative diseases } \\
\text { targeting CDK5/p25, CK1 } 1 \delta \text {, and } \\
\text { GSK3 } \beta \text { kinases. Inhibits the } \\
\text { Gram-positive bacteria Bacillus } \\
\text { subtilis (ATCC } 6051 \text { and } 6633 \text { ) }\end{array}$ & [79] \\
\hline
\end{tabular}


Table 2. Cont.

\begin{tabular}{|c|c|c|c|c|c|}
\hline $\begin{array}{l}\text { Natural } \\
\text { Compound }\end{array}$ & Chemical Structure & Species & $\begin{array}{l}\text { Biological } \\
\text { Activity }\end{array}$ & Mechanism of action & References \\
\hline $\begin{array}{l}\text { Sargaquinoic } \\
\text { acid }\end{array}$ & & $\begin{array}{c}\text { Brown alga/ } \\
\text { Sargassum sagamianum }\end{array}$ & AChE inhibitor & $\begin{array}{l}\text { Inhibits } \\
\text { acetylcholinesterase activity }\end{array}$ & [80] \\
\hline $\begin{array}{c}\text { Phorbasterone } \\
\text { B }\end{array}$ & & Red seaweed & Antimicrobial & $\begin{array}{c}\text { Exhibits antimicrobial activity } \\
\text { against Bacillus cereus, } \\
\text { Staphylococcus aureus, } \\
\text { Streptococcus pneumoniae, and } \\
\text { Candida albicans }\end{array}$ & [81] \\
\hline $\begin{array}{l}\text { Azocinyl- } \\
\text { morpholinone }\end{array}$ & & $\begin{array}{l}\text { Red seaweed/ } \\
\text { Gracilaria opuntia }\end{array}$ & $\begin{array}{l}\text { Antioxidant, } \\
\text { anti-inflammatory } \\
\text { by inhibiting } \\
\text { cyclooxygenase } \\
\text { and lipoxygenase }\end{array}$ & $\begin{array}{c}\text { Azocinyl morpholinone } \\
\text { significantly mitigated the } \\
\text { carrageenan-induced paw edema }\end{array}$ & [82] \\
\hline $\begin{array}{l}\text { (5Z)-4-bromo-5- } \\
\text { (bromo-methylene)-3- } \\
\text { butyl-2(5H)-furanone }\end{array}$ & & $\begin{array}{l}\text { Red seaweed/ } \\
\text { Delisea pulchra }\end{array}$ & Antifouling agent & $\begin{array}{l}\text { Inhibits microbial-induced } \\
\text { corrosion related to } \\
\text { Gram-positive bacteria }\end{array}$ & [83] \\
\hline
\end{tabular}


Table 2. Cont.

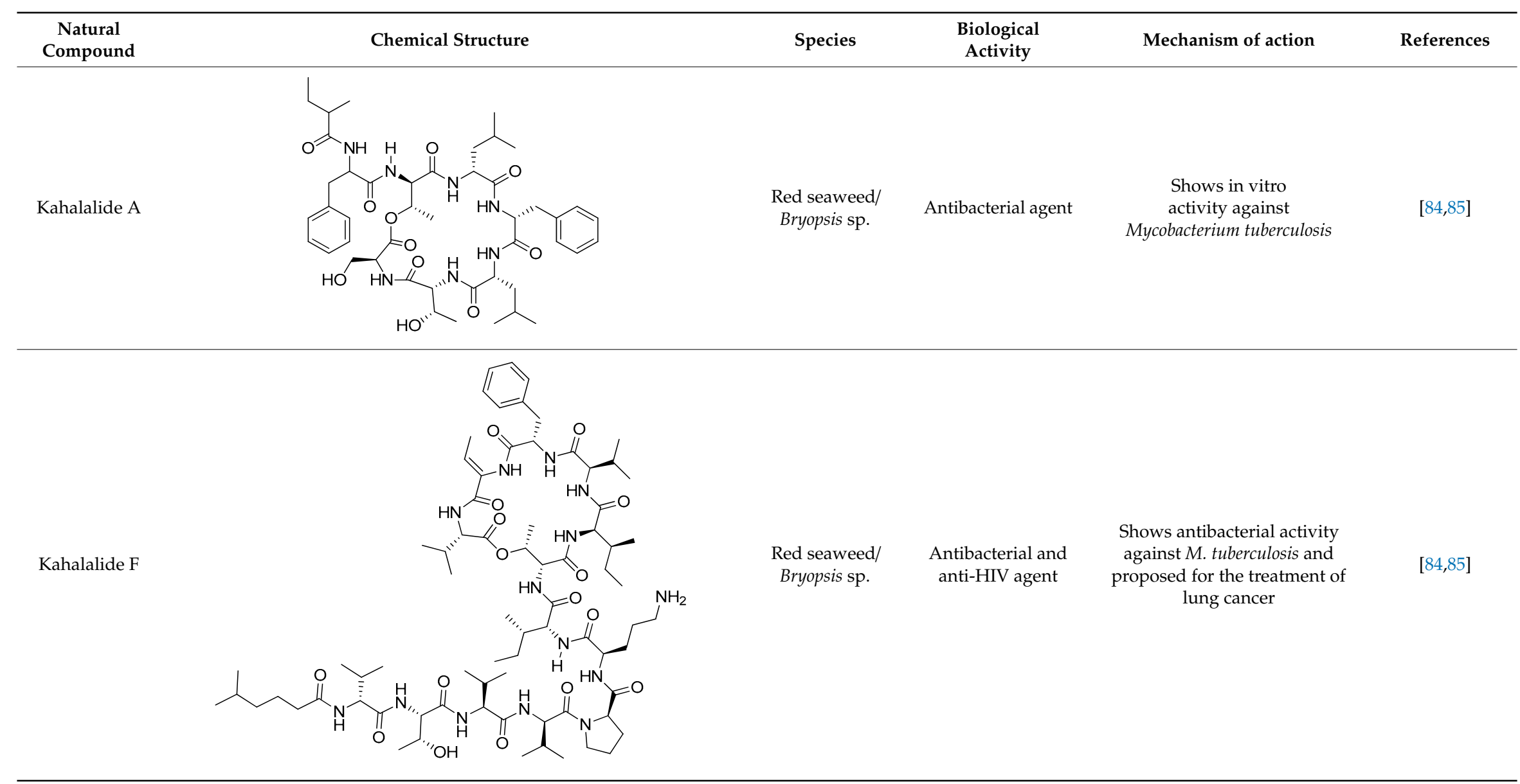




\subsubsection{Red Seaweeds}

Red seaweeds are commonly considered beneficial for human health and an important source of bioactive compounds [86]. For centuries, their extracts have been applied for the cure of asthma, thyroid goiter, urinary infections, stomach ulcers, and even tumors. Among the compounds isolated from red seaweeds, sulfated polysaccharides are economically the most important bioactive compound because of their wide application in medicine. These polysaccharides are carrageenan, agar (Figure 4A), agarose, and furcellaran (Danish agar). Carrageenan is produced by the genera Chondrus, Eucheuma, Gigartina, and Iridea and is considered an effective remedy for gastric and duodenal ulcers [87]. Chondrus crispus is a good source of carrageenan that has an antiviral property, in particular against influenza B and mumps virus [88]. Agar and agarose are used for interferon production, usage as antiviral compounds, and improving B- and T-cell activity [89]. A polysaccharide ( $\mathrm{Mw}=100-500 \mathrm{kDa})$ isolated from the fermented red seaweed Lomentaria catenata possesses anticoagulant activity [90]. Fucoidan (Figure 4F), extracted from Gracilaria corticata, showed activity against both colorectal and breast cancer [91]. An anthelmintic compound, L- $\alpha$-kainic acid (Figure 4B), has been isolated from Digenea simplex [92]. Deepa et al. (2017) reported on the possible effects of G. corticata on cancer treatments, inflammation, and infectious diseases [91]. Some red seaweeds, such as Rhodomela confervoides, Symphyocladia latiuscula, and Polysiphonia urceolata, produce phenolic compounds, which have shown antidiabetic activity. These compounds possess the capacity to inhibit protein tyrosine phosphatase (PTPase), which is responsible for the response to insulin. Collins reported on the antiasthmatic activity of polyphenolic extracts of Laurencia undulate [68]. A new potent inhibitor of lipoxygenase (LOX), which plays a crucial role in neurodegeneration, has been isolated from Odonthalia corymbifera [93]. The substance is pheophytin A, which can be applied as a new therapeutic, and is considered an excellent opportunity for the treatment of neuropathologies such as Alzheimer's disease. 
<smiles>CO[C@H]1[C@@H](O)[C@@H](CO)OC(OC2C3CO[C@@H]2[C@H](O)C(C)O3)[C@@H]1O</smiles>

A<smiles>C[C@@H]1O[C@H](C)[C@@H](OS(=O)(=O)O)[C@@H](O)[C@@H]1O</smiles><smiles>C=C(C)[C@H]1CNC(C(=O)O)C1CC(=O)O</smiles><smiles></smiles>

B<smiles>CC1=CC(=O)C=C(C[C@@H]2[C@@H]3CCC(=C(C)C)[C@H](CCC(=O)O)[C@@]3(C)CC[C@H]2C)C1=O</smiles>

C
G<smiles>CC(=O)O/C=C(/C=C/OC(C)=O)C(CC=C(C)C#CC=C(C)C)OC(C)=O</smiles>

H<smiles>CC1=C[C@H](O)CC(C)(C)C1CC(=O)/C(=C/C=C/C(C)=C/C=C/C=C(C)/C=C/C=C(C)/C=C/[C@H]1C(C)=C[C@@H](O)CC1(C)C)CO</smiles>

D<smiles>CC1=C[C@H](O)CC(C)(C)[C@H]1/C=C/C(C)=C/C=C/C(C)=C/C=C/C=C(C)/C=C/C=C(C)/C=C/C1=C(C)C[C@@H](O)CC1(C)C</smiles><smiles></smiles>

I

Figure 4. Chemical structure of marine natural compounds isolated from marine macroalgae. (A) Agar; (B) Alpha-Allokainic acid; (C) Stypoquinonic acid; (D) Siphonaxanthin; (E) Lutein; (F) Fucoidan; (G) 8,8'-Bieckol; (H) Caulerpenyne; (I) Phlorofucofuroeckol A; (J) Sodium alginate.

Antiviral Activity

Witvrouw et al. (1994) isolated a polysaccharide, galactan sulfate, from Agardhiella tenera that showed activity against HIV-1 and HIV-2, with $\mathrm{IC}_{50}$ values of 0.5 and $0.05 \mu \mathrm{g} / \mathrm{L}$, respectively [94]. Devi et al. reported on the antioxidant and antimicrobial activity of the methanolic extracts of different Indian red seaweeds [95]. An antiviral compound, sulfated xylomannan, has been extracted from the Indian red seaweed Scinaia hatei that inhibited HSV-1 and HSV-2 $\left(\mathrm{IC}_{50}=0.5-1.4 \mu \mathrm{g} / \mathrm{mL}\right)[96]$. Water-soluble polysaccharidic extracts of Sphaerococcus coronopifolius and Boergeseniella thuyoides collected from the coast of Morocco showed antiviral properties against viruses, including HIV and HSV-1 [97]. Serkedjieva (2004) extracted a bioactive compound from Ceramium rubrum isolated from the Black Sea. This metabolite inhibited types A and B influenza viruses, both in vivo and in vitro, followed by the reduction of cytopathogenic effects [98]. 


\section{Antioxidant Activity}

Antioxidant properties has been found in several species of red seaweeds, including Gracilaria, Halymenia, Laurencia, Ahnfeltiopsis, and Polysiphonia. For example, mycosporine-like amino acids isolated from Ahnfeltiopsis devoniensis show antioxidant activity [99]. Moreover, two classes of natural compounds, polyphenols and bromophenols, with known antioxidant activity were isolated from red seaweeds [100]. The ethanolic [101] and methanolic [102] extracts isolated from Gracilaria tenuistipitata showed antiproliferative activity on the oral carcinoma cell line Ca 9-22 by modulating oxidative-stress-induced cell apoptosis.

\section{Antibiotic Activity}

Rahelivao reported on the properties of crude extracts of the red algae Laurencia complanata, which displayed antibacterial activity against Streptococcus pneumoniae, Bacillus cereus, and S. aureus [81]. Four tetracyclic brominated 1, 4-diterpenes were isolated from the extract of S. coronopifolius, collected from the rocky coasts of Corfu Island (Greece). These diterpenes showed antibiotic activity against a panel of bacteria, including methicillin-resistant S. aureus (MRSA) and MDR strains, with MIC (Minimum Inhibitory Concentrations) values in the $16-128 \mu \mathrm{g} / \mathrm{mL}$ range [103]. Crude methanolic extracts isolated from Acanthaphora spicifera showed antibacterial activity against E. coli, Bacillus subtilis, Pseudomonas aeruginosa, and Bacillus palmitus [104]. Also, antifungal activity of the extracts against $C$. albicans, Aspergillus niger, and Microsporum gypseum was observed [105].

\section{Antitumor and Anticoagulant Activities}

A novel polyhalogenated monoterpene, halomon, isolated from Portieria hornemannii, shows cytotoxic action against numerous human tumor cell lines (brain, kidney, and colon) and is currently in the preclinical testing phase [106]. Moreover, Andrianasolo (2006) isolated three halomon derivatives from P. hornemannii, which exhibited inhibitory effects on the DNA methyltransferase-1 enzyme [107]. Among other functions, DNA methyltransferase has a profound role in epigenetics and gene expression. The anticoagulant activity of sulfated polysaccharides derived from Delesseria sanguinea (Ceramiales) [108] and a sulfated galactan fraction from Botryocladia occidentalis (Rhodymeniales) was reported [109]. Matsuhiro et al. (2005) reported on an antiviral sulfated galactan from Schizymenia binderi [110]. Moreover, Botryocladia leptopoda extracts exhibited stimulant activities on the central nervous system (CNS) in a mouse model [111].

\subsubsection{Brown Seaweeds}

Brown seaweeds contain several pigments, such as fucoxanthin, violaxanthin, and $\beta$-carotene [112]. Fucoxanthin occurs in edible marine brown algae, including Undaria pinnatifida, Laminaria japonica, Sargassum fulvellum, and Hijikia fusiformis, and possesses antioxidant, anticancer, antiobesity, antidiabetic, and antiphotoaging activities [113]. The ethanolic extract of Turbinaria conoides demonstrated antioxidant, antibacterial, and anticancer properties. The sources and properties of some bioactive principles in the extracts of brown seaweeds are reported in Table 2. For example, organic solvent extracts from Sargassum wightii and Sargassum ilicifolium exhibited an interesting anticancer activity on several cells lines [114]. Several studies on $U$. pinnatifida demonstrated anti-hyperglycemic, antitumor, anti-hypertensive, and antiobesity potential [115]. Khan reported on an omega-3 essential fatty acid, stearidonic acid, isolated from $U$. pinnatifida which showed activity against erythema, mouse ear inflammation, edema, and blood flows $\left(\mathrm{IC}_{50}=160,314\right.$, and $235 \mu \mathrm{g} /$ per ear, respectively) [116]. Laminarin is a water-soluble polysaccharide found in brown algae that has strong heparin-like activity and, therefore, is useful as an anticoagulant, antilipemic, antiviral, or anti-inflammatory agent [17]. Park et al. (2011) reported that that fucoidan reduces lipid accumulation by stimulating lipolysis, and it can be beneficial for obesity therapy [117]. Spavieri reported on the antimycobacterial, antiprotozoal, and cytotoxic activity of 21 brown algae (Phaeophyceae) from British and Irish waters [118]. Several other bioactive 
compounds were reported for fucoidans isolated from different species of brown algae, including antiviral and antibacterial activities [119]. Moreover, fucoidans isolated from brown seaweed species present immunomodulating activity, involving the increased generation of macrophage-mediated responses such as interleukin-2 (IL-2), interleukin-12 (IL-12), and interferon gamma (IFN- $\gamma$ ) [120]. Salgado reported on the interactions between polyphenolic compounds from the brown alga Padina gymnospora and cell wall alginates, leading to the absorption of ultraviolet radiation [121]. Also, diekol isolated from Ecklonia cava showed antifungal, anti-inflammatory, and anti-type-II diabetes activities in mouse models [122].

Antibacterial and Antioxidant Activities

The essential oil derived from $U$. pinnatifida possesses potent antibacterial and antioxidant activities [114]. The methanolic extracts of Sargassum platycarpum A and Sargassum latifolium B were shown to be highly effective against Gram-positive bacteria [123]. Three novel products from Ecklonia maxima-eckol, dibenzo-dioxine-2,4,7,9-tetraol, and phloroglucinol-were shown to exhibit free-radical scavenging activity by a $\mathrm{DPPH}$ assay, and the $\mathrm{EC}_{50}$ values were $0.008,0.012$, and $0.128 \mu \mathrm{M}$, respectively [124]. The phenolic extracts of Sargassum showed antibacterial and antioxidant properties [125].

\section{Antidepressant Activity}

Extracts of Sargassum swartzii and Stoechospermum marginatum showed significant stimulant and anxiolytic effects on a rat model, which occurred by the amelioration of brain norepinephrine levels [126]. The aqueous extracts of Cystoseira usneoides, Cystoseira tamarascifolia, Cystoseira nodicaulis, Stypocaulon scoparium, and Fucus spiralis showed antidepressant activity by inhibiting the monoamine oxidase A (MAO-A) enzyme [127].

\section{Anticancer Activity}

A cytotoxic metabolite, stypoldione, isolated from Stypodium zonale inhibited microtubule polymerization, thereby preventing mitotic spindle formation in cell cultures [128]. Ethanolic extracts of $U$. pinnatifida sporophylls induced nonoxidative apoptotic damage on human colon or rectum cancer cells [129]. The derivative of atomaric acid, stypoquinonic acid (Figure 4C), isolated from S. zonale is an inhibitor of the tyrosine kinase enzyme. Another atomaric acid derivative, dimethoxy-atomaric acid, showed cytotoxic activity against lung and colon cancer cells [130]. Moreover, fucoidan is known to possess other bioactive properties, such as inhibitory effects on the growth of cancer cells [131]. Sodium alginate (Figure 4J) obtained from brown seaweeds has shown antitumor and anti-inflammatory properties [132]. The anticancer activity was evaluated by analyzing the effects on the cell cycle and apoptosis induction on HepG2 cells [133]. Furthermore, several studies validated the apoptosis induction ability of fucoidans in various tumor cell lines, including melanoma cells, colon cancer, lymphoma, and breast cancer cells [134].

\section{Antiangiogenic and Anticoagulant Activities}

Phlorofucofuroeckol A (Figure 4I), a phlorotannin (Figure 4H) from Ecklonia kurome, exhibited inhibitory activity on the angiotensin-converting enzyme, with an $\mathrm{IC}_{50}$ value of $12.74 \mu \mathrm{M}$ [135]. The sulfated polysaccharides known as fucoidans caused the prevention of cell proliferation and migration and also vascular network formation on human umbilical vein endothelial cells (HUVEC), suggesting significant antiangiogenic activity [136]. Remarkably, this effect deteriorated upon the reduction of fucoidan molecular weight $(<30 \mathrm{kDa})$ [137]. An analogous observation was reported for the anticoagulant activities of fucoidans [138]. A fucoidan isolated from Fucus vesiculosus showed antithrombotic activity [139]. 


\section{Antiviral Activity}

Phlorotannin derivatives extracted from E. cava, 8,4'-dieckol and 8,8'-bieckol (Figure 4G), displayed an anti-HIV-1 property by inhibiting the viral reverse transcriptase and the protease at concentrations $\left(\mathrm{IC}_{50}\right)$ of 5.3 and $0.5 \mu \mathrm{M}$, respectively [140]. Hayashi et al. studied the fucoidan from U. pinnatifida and described its defensive effects against herpes simplex virus (HSV) infections [141]. Also, Queiroz reported on a brown seaweed polysaccharide inhibiting the activity of the reverse transcriptase of HIV [142]. Fucans from Dictyota mertensii, F. vesiculosus, Spatoglossum schroederi, and Lobophora variegate show inhibitory effects on the reverse transcriptase of HIV-1 [143].

\section{Antiparasitic Activity}

Soares demonstrated that brown algae belonging to the family of Dictyotaceae, namely Dictyota pfaffii and Canistrocarpus cervicornis, possess antileishmania activity [144]. Nara reported that the extracts from Pelvetia babingtonii and Fucus evanescens contain inhibitors of dihydroorotate dehydrogenase, a virulence agent of Trypanosoma cruzi, the protozoa responsible of the Chagas disease [145]. Dolabelladienetriol, a diterpene derived from $D$. pfaffii, showed killing effects against Leishmania intracellular amastigotes $\left(\mathrm{IC}_{50}=44 \mu \mathrm{M}\right)$ as well as anti-HIV-1 activities [146]. Eleganolone (Figure 3), another diterpene from Bifurcaria bifurcate, exerted strong inhibitory activity $\left(\mathrm{IC}_{50}=0.53 \mu \mathrm{g} / \mathrm{mL}\right)$ against the bloodstream forms of Trypanosoma brucei rhodesiense [147].

Of course, the clinical application of all these substances depends on further studies and safety evaluations.

\subsubsection{Green Seaweeds}

Green seaweeds, or chlorophyta, are a large group of macroalgae with worldwide distribution. The morphology of some species is presented in Figure 3. Green seaweeds are highly considered for their production of antioxidants, vitamins, and bioactive peptides [148]. Among their bioactive constituents, cell wall polysaccharides, constituting about $38-54 \%$ of the seaweed dry matter, show pharmaceutical potential [149]. Some green seaweeds, such as Caulerpa taxifolia, Caulerpa racemose, and Cladophora pinnulata, show hypotensive activities [111]. At the moment, most of the literature on green seaweed products is focused on sulfated polysaccharides because of their interesting properties, including anticoagulant, antioxidant, anticancer, anti-hyperlipidemic, and immunomodulation effects [150]. Ulvan, a sulfated polysaccharide form Ulva pertusa, has valuable antioxidant activity [151]. It also acts on the plasma levels of low-density lipoprotein (LDL), high-density lipoprotein (HDL), and triglycerides in mice and can be useful for ischemic, cerebrovascular, and cardiovascular diseases [152]. Sulfated polysaccharides from $U$. pertusa, Capsosiphon fulvescens, and Codium fragile possess potent immune-modulating activity by stimulating macrophages [153]. Also, the ethanolic extracts of Codium tomentosum showed antigenotoxic and antioxidant effects [154] and Codium decorticatum showed antibacterial activity [155]. Moreover, methanolic extracts of Ulva linza, due to their high polyunsaturated fatty acids (PUFA) content, showed high inhibitory activity against inflammatory response [156].

\section{Antiviral Activity}

Sulfated polysaccharides from nine different green seaweeds (Caulerpa brachypus, Caulerpa scapelliformis, Caulerpa okamurai, Chaetomorpha crassa, Chaetomorpha spiralis, Monostroma nitidum, C. fragile, Codium adhaerens, and Codium latum) exhibited strong activity against type 1 herpes virus, with the $\mathrm{IC}_{50}$ ranging from 0.38 to $8.5 \mu \mathrm{g} / \mathrm{mL}$, while presenting low cytotoxicity [157]. Rhamnan sulfate, another sulfated polysaccharide from $M$. nitidum, was effective against type 2 herpes virus by inhibiting its adsorption and penetration onto host cells [78]. In a study carried out by Sato et al. (2011), a high-mannose-binding lectin was isolated from Boodlea coacta. This lectin showed antiviral activity against HIV-1 infections $\left(\mathrm{EC}_{50}=8.2 \mathrm{nM}\right)$ and influenza viruses [158]. The potent anti-HIV-1 
activity was related to the carbohydrate-binding tendency, formerly reported for other antiviral lectins. In addition, ethanolic extracts of Codium elongatum and Ulva fasciata exhibited antiviral activity against the Semliki forest and Vaccinia viruses [111].

\section{Antioxidant and Anticancer Activities}

According to Wang, extracts and monounsaturated fatty acids (MUFA) derivatives from Ulva lactuca induced an antioxidant response in cells [159]. Beta-carotene is a potent antioxidant found in green seaweeds and can be accumulated in very high amounts in Dunaliella salina [160]. Carotenoids, for example, lutein (Figure 4E) and zeaxanthin from the green seaweed Chlorococcum humicola, exhibited antimutagenic activity against benzo[a]pyrene-induced mutations in histidine-revertant cells of Salmonella typhimurium and were proposed for the reduction of the breast cancer risks [161]. Another carotenoid from green seaweeds, siphonaxanthin (Figure 4D), effectively induced apoptosis in human leukemia (HL-60) cells by caspase-3 activation, accompanied by the modification of growth arrest and DNA-damage-inducible protein (GADD45 $\alpha$ ), tumor necrosis factor receptors (DR5/TRAIL receptor-2), and Bcl-2 regulatory protein expression pattern [162]. Ganesan reported that siphonaxanthin derived from C. fragile possesses considerable antiangiogenic activity [163]. Moreover, the ethanolic extracts of C. tomentosum showed antigenotoxic and antioxidant effects [154].

\section{Antibacterial and Antifouling Activities}

Extracts of $U$. fasciata isolated from the southeast coast of India displayed antibacterial properties and a broad spectrum of antibiotic activity against B. cereus, E. coli, B. subtilis, Aeromonas hydrophila, Vibrio fischeri, and Vibrio harveyi [164]. Cladophora glomerata exhibited significant antibacterial activity against the MDR bacterium Acinetobacter baumannii and various human and fish pathogens, such as E. coli, B. cereus, Vibrio anguillarum, V. fischeri, Vibrio parahaemolyticus, and Vibrio vulnificus [165]. An acetylenic sesquiterpene isolated from Caulerpa prolifera, caulerpenyne (Figure $4 \mathrm{H}$ ), exhibited antifouling activity against bacteria and the microalga Phaeodactylum tricornutum [166]. Moreover, the ethanolic extracts of $C$. decorticatum showed antibacterial activity [155]

\section{Anticoagulant Activity}

The earliest report on the anticoagulant effects of substances produced by green seaweeds were carried out on Codium, in particular on C. fragile ssp. tomentosoides [167]. Matsubara also reported on the anticoagulant activity of a sulfated galactan in the Codium genus [168]. Furthermore, Maeda described that sulfated polysaccharides from the marine green alga M. nitidum yielded a sixfold higher anticoagulant effect than heparin [169]. Also, Synytsya reported on the anticoagulant activity of sulfated polysaccharides derived from C. fulvescens [170].

The findings presented above suggest that green marine algae can be considered a promising source of bioactive substances, which should be further studied and exploited for pharmaceutical applications. Some of the biological activities of compounds extracted from marine seaweeds are presented in Table 2.

\section{Concluding Remarks}

The marine environment represents a unique source of bioactive compounds with high pharmaceutical potential. Preclinical and clinical studies are in progress for a number of marine organism derivatives. Nevertheless, several problems should be solved for a deep characterization of biomolecules derived from marine microorganisms, micro, and macroalgae. Notably, marine microbes are notoriously difficult to prepare and maintain in culture. Bacteria likely grow as consortia in the marine environment and dependences on other bacteria for essential nutrients should be guaranteed. These interactions are lacking in isolated laboratory cultures. Further, the marine shear stress, hypersalinity, and antagonists, which induce unique metabolite elaborations, are missing in laboratory cultures. That notwithstanding, these efforts may lead to valuable results. In fact, marine 
bacteria are significant reservoirs of a plethora of bioactive molecules which have never been found in terrestrial organisms. Moreover, microalgae represent an important, still underestimated source of bioactive metabolites, such as antiviral and anti-AIDS agents. Seaweeds as well produce many different, interesting biologically active substances, such as sulphated polysaccharides, which are promising compounds for drug development [171]. For example, carbohydrate recognition molecules, such as lectins from green seaweeds, have the potential to be used as antitumor and antiviral agents, but they have been rarely investigated [172]. Notably, a natural compound can have variable effects on the human body, as host factors are different. The promising results obtained by an in vitro experiment may not show the same effects in a patient's body. Moreover, the human body under an inflammatory process presents an activated immune system that can consider even a therapeutic compound a threat. Thus, proper safety assessments of the studied metabolites are required. The optimal dosage determination is very important, as this parameter distinguishes whether a compound will act as a drug or a poison. From a technological point of view, novel cost-effective and large-scale fermentation strategies ought to be devised, and particular attention should be paid to the conditions under which the secondary metabolites are produced. Recreating the physical, chemical, and biological conditions of a marine environment is hardly an achievable task. Metabolic and protein engineering can improve the efficacy of some of the marine candidates with pharmaceutical potential. In the future, the efforts and advances in this direction will certainly open the way for extraordinary discoveries for novel applications of marine-derived compounds in biotechnology and biomedicine.

Author Contributions: Conceptualization, writing and original draft preparation, N.B.; software, H.B.P.; editing, S.T.J.; review, revision and funding acquisition, F.V.

Funding: This research was funded by Veneto Region project "Safe, Smart, Sustainable Food for Health (3S_4H)"-POR FESR 2014-2020, 1.1.4. DGR n. 1139.

Acknowledgments: Authors gratefully acknowledge the excellence department project of the Italian Ministry of Education, University and Research (MIUR) "Excellence for Aquatic Animal Health-ECCE AQUA".

Conflicts of Interest: The authors declare no conflict of interest.

\section{References}

1. Jahromi, S.T.; Barzkar, N. Marine bacterial chitinase as sources of energy, eco-friendly agent, and industrial biocatalyst. Int. J. Biol. Macromol. 2018, 120, 2147-2154. [CrossRef] [PubMed]

2. Rey-Ladino, J.; Ross, A.G.; Cripps, A.W.; McManus, D.P.; Quinn, R. Natural products and the search for novel vaccine adjuvants. Vaccine 2011, 29, 6464-6471. [CrossRef] [PubMed]

3. Donia, M.; Hamann, M.T. Marine natural products and their potential applications as anti-infective agents. Lancet Infect. Dis. 2003, 3, 338-348. [CrossRef]

4. Proksch, P.; Edrada, R.; Ebel, R. Drugs from the seas-current status and microbiological implications. Appl. Microbiol. Biotechnol. 2002, 59, 125-134.

5. Blunt, J.W.; Copp, B.R.; Hu, W.-P.; Munro, M.H.; Northcote, P.T.; Prinsep, M.R. Marine natural products. Nat. Prod. Rep. 2009, 26, 170. [CrossRef] [PubMed]

6. Jahromi, S.T.; Barzkar, N. Future direction in marine bacterial agarases for industrial applications. Appl. Microbiol. Biotechnol. 2018, 102, 6847-6863. [CrossRef] [PubMed]

7. McArthur, K.A.; Mitchell, S.S.; Tsueng, G.; Rheingold, A.; White, D.J.; Grodberg, J.; Lam, K.S.; Potts, B.C. Lynamicins a-e, chlorinated bisindole pyrrole antibiotics from a novel marine actinomycete. J. Nat. Prod. 2008, 71, 1732-1737. [CrossRef] [PubMed]

8. Baker, J.T. Seaweeds in pharmaceutical studies and applications. In XIth International Seaweed Symposium; Bird, C.J., Ragan, M.A., Eds.; Kluwer Academic Publishers Group: Qingdao, China, 1984; Volume 116/117, pp. 29-40.

9. El-Gendy, M.M.; Hawas, U.W.; Jaspars, M. Novel bioactive metabolites from a marine derived bacterium nocardia sp. Alaa 2000. J. Antibiot. 2008, 61, 379. [CrossRef] [PubMed]

10. Gil-Turnes, M.S.; Hay, M.E.; Fenical, W. Symbiotic marine bacteria chemically defend crustacean embryos from a pathogenic fungus. Science 1989, 246, 116. [CrossRef] 
11. Deshmukh, S.K.; Prakash, V.; Ranjan, N. Marine fungi: A source of potential anticancer compounds. Front. Microbiol. 2018, 8, 2536. [CrossRef]

12. Nguyen, H.P.; Zhang, D.; Lee, U.; Kang, J.S.; Choi, H.D.; Son, B.W. Dehydroxychlorofusarielin b, an antibacterial polyoxygenated decalin derivative from the marine-derived fungus aspergillus sp. J. Nat. Prod. 2007, 70, 1188-1190. [CrossRef] [PubMed]

13. Trisuwan, K.; Rukachaisirikul, V.; Sukpondma, Y.; Preedanon, S.; Phongpaichit, S.; Rungjindamai, N.; Sakayaroj, J. Epoxydons and a pyrone from the marine-derived fungus nigrospora sp. Psu-f5. J. Nat. Prod. 2008, 71, 1323-1326. [CrossRef] [PubMed]

14. Newman, D.J.; Cragg, G.M. Marine natural products and related compounds in clinical and advanced preclinical trials. J. Nat. Prod. 2004, 67, 1216-1238. [CrossRef] [PubMed]

15. Prachyawarakorn, V.; Mahidol, C.; Sureram, S.; Sangpetsiripan, S.; Wiyakrutta, S.; Ruchirawat, S.; Kittakoop, P. Diketopiperazines and phthalides from a marine derived fungus of the order pleosporales. Planta Med. 2008, 74, 69-72. [CrossRef] [PubMed]

16. Xu, J.; Kjer, J.; Sendker, J.; Wray, V.; Guan, H.; Edrada, R.; Lin, W.; Wu, J.; Proksch, P. Chromones from the endophytic fungus pestalotiopsis sp. Isolated from the chinese mangrove plant rhizophora mucronata. J. Nat. Prod. 2009, 72, 662-665. [CrossRef] [PubMed]

17. Pal, A.; Kamthania, M.C.; Kumar, A. Bioactive compounds and properties of seaweeds-A review. Open Access Libr. J. 2014, 1, 1. [CrossRef]

18. Debbab, A.; Aly, A.H.; Lin, W.H.; Proksch, P. Bioactive compounds from marine bacteria and fungi. Microb. Biotechnol. 2010, 3, 544-563. [CrossRef] [PubMed]

19. Lee, D.-S.; Jang, J.-H.; Ko, W.; Kim, K.-S.; Sohn, J.H.; Kang, M.-S.; Ahn, J.S.; Kim, Y.-C.; Oh, H. Ptp1b inhibitory and anti-inflammatory effects of secondary metabolites isolated from the marine-derived fungus penicillium sp. Jf-55. Mar. Drugs 2013, 11, 1409-1426. [CrossRef] [PubMed]

20. Lam, K.S.; Tsueng, G.; McArthur, K.A.; Mitchell, S.S.; Potts, B.C.; Xu, J. Effects of halogens on the production of salinosporamides by the obligate marine actinomycete salinispora tropica. J. Antibiot. 2007, 60, 13-19. [CrossRef] [PubMed]

21. Nicholson, B.; Lloyd, G.K.; Miller, B.R.; Palladino, M.A.; Kiso, Y.; Hayashi, Y.; Neuteboom, S.T. Npi-2358 is a tubulin-depolymerizing agent: In-vitro evidence for activity as a tumor vascular-disrupting agent. Anti-Cancer Drugs 2006, 17, 25-31. [CrossRef]

22. Kim, M.-Y.; Sohn, J.H.; Ahn, J.S.; Oh, H. Alternaramide, a cyclic depsipeptide from the marine-derived fungus alternaria sp. Sf-5016. J. Nat. Prod. 2009, 72, 2065-2068. [CrossRef] [PubMed]

23. Lu, X.; Xu, Q.Z.; Shen, Y.; Liu, X.; Jiao, B.; Zhang, W.; Ni, K. Macrolactin s, a novel macrolactin antibiotic from marine bacillus sp. Nat. Prod. Res. 2008, 22, 342-347. [CrossRef] [PubMed]

24. Koizumi, Y.; Arai, M.; Tomoda, H.; Omura, S. Fungerin, a fungal alkaloid, arrests the cell cycle in $\mathrm{m}$ phase by inhibition of microtubule polymerization. J. antIbiot. 2004, 57, 415-420. [CrossRef] [PubMed]

25. Kwan, J.C.; Eksioglu, E.A.; Liu, C.; Paul, V.J.; Luesch, H. Grassystatins a-c from marine cyanobacteria, potent cathepsin e inhibitors that reduce antigen presentation. J. Med. Chem. 2009, 52, 5732-5747. [CrossRef] [PubMed]

26. Taniguchi, M.; Nunnery, J.K.; Engene, N.; Esquenazi, E.; Byrum, T.; Dorrestein, P.C.; Gerwick, W.H. Palmyramide a, a cyclic depsipeptide from a palmyra atoll collection of the marine cyanobacterium lyngbya majuscula. J. Nat. Prod. 2009, 73, 393-398. [CrossRef]

27. Medina, R.A.; Goeger, D.E.; Hills, P.; Mooberry, S.L.; Huang, N.; Romero, L.I.; Ortega-Barría, E.; Gerwick, W.H.; McPhail, K.L. Coibamide a, a potent antiproliferative cyclic depsipeptide from the panamanian marine cyanobacterium leptolyngbya sp. J. Am. Chem. Soc. 2008, 130, 6324-6325. [CrossRef] [PubMed]

28. Yao, G.; Pan, Z.; Wu, C.; Wang, W.; Fang, L.; Su, W. Efficient synthesis and stereochemical revision of coibamide a. J. Am. Chem. Soc. 2015, 137, 13488-13491. [CrossRef] [PubMed]

29. Ramaswamy, A.V.; Sorrels, C.M.; Gerwick, W.H. Cloning and biochemical characterization of the hectochlorin biosynthetic gene cluster from the marine cyanobacterium lyngbya majuscula. J. Nat. Prod. 2007, 70, 1977-1986. [CrossRef] [PubMed]

30. Matthew, S.; Ross, C.; Paul, V.J.; Luesch, H. Pompanopeptins a and b, new cyclic peptides from the marine cyanobacterium lyngbya confervoides. Tetrahedron 2008, 64, 4081-4089. [CrossRef]

31. Plaza, M.; Cifuentes, A.; Ibáñez, E. In the search of new functional food ingredients from algae. Trends Food Sci. Technol. 2008, 19, 31-39. [CrossRef] 
32. Imhoff, J.F.; Labes, A.; Wiese, J. Bio-mining the microbial treasures of the ocean: New natural products. Biotechnol. Adv. 2011, 29, 468-482. [CrossRef] [PubMed]

33. Plaza, M.; Herrero, M.; Cifuentes, A.; Ibáñez, E. Innovative natural functional ingredients from microalgae. J. Agric. Food Chem. 2009, 57, 7159-7170. [CrossRef] [PubMed]

34. Mimouni, V.; Ulmann, L.; Pasquet, V.; Mathieu, M.; Picot, L.; Bougaran, G.; Cadoret, J.-P.; Morant-Manceau, A.; Schoefs, B. The potential of microalgae for the production of bioactive molecules of pharmaceutical interest. Curr. Pharmac. Biotechnol. 2012, 13, 2733-2750. [CrossRef]

35. Kim, S.-K.; Karadeniz, F. Anti-hiv activity of extracts and compounds from marine algae. Adv. Food Nutr. Res. 2011, 64, 255-265. [PubMed]

36. Yim, J.H.; Kim, S.J.; Ahn, S.H.; Lee, C.K.; Rhie, K.T.; Lee, H.K. Antiviral effects of sulfated exopolysaccharide from the marine microalga gyrodinium impudicum strain kg03. Mar. Biotechnol. 2004, 6, 17-25. [CrossRef] [PubMed]

37. Nuhu, A.A. Spirulina (arthrospira): An important source of nutritional and medicinal compounds. J. Mar. Biol. 2013, 2013, 1-8. [CrossRef]

38. Xu, Y.; He, H.; Schulz, S.; Liu, X.; Fusetani, N.; Xiong, H.; Xiao, X.; Qian, P.-Y. Potent antifouling compounds produced by marine streptomyces. Bioresour. Technol. 2010, 101, 1331-1336. [CrossRef] [PubMed]

39. Tan, L.T.; Goh, B.P.L.; Tripathi, A.; Lim, M.G.; Dickinson, G.H.; Lee, S.S.C.; Teo, S.L.M. Natural antifoulants from the marine cyanobacterium lyngbya majuscula. Biofouling 2010, 26, 685-695. [CrossRef]

40. Sivonen, K.; Leikoski, N.; Fewer, D.P.; Jokela, J. Cyanobactins-Ribosomal cyclic peptides produced by cyanobacteria. Appl. Microbiol. Biotechnol. 2010, 86, 1213-1225. [CrossRef]

41. Taori, K.; Matthew, S.; Rocca, J.R.; Paul, V.J.; Luesch, H. Lyngbyastatins 5-7, potent elastase inhibitors from floridian marine cyanobacteria, lyngbya spp. J. Nat. Prod. 2007, 70, 1593-1600. [CrossRef]

42. Volk, R.-B.; Furkert, F.H. Antialgal, antibacterial and antifungal activity of two metabolites produced and excreted by cyanobacteria during growth. Microbiol. Res. 2006, 161, 180-186. [CrossRef] [PubMed]

43. Tiwari, A.; Sharma, D. Antibacterial activity of bloom forming cyanobacteria against clinically isolated human pathogenic microbes. J. Algal Biomass Utilization 2013, 4, 83-89.

44. Martins, R.F.; Ramos, M.F.; Herfindal, L.; Sousa, J.A.; Skærven, K.; Vasconcelos, V.M. Antimicrobial and cytotoxic assessment of marine cyanobacteria-synechocystis and synechococcus. Mar. Drugs 2008, 6, 1-11. [CrossRef] [PubMed]

45. Jaki, B.; Orjala, J.; Sticher, O. A novel extracellular diterpenoid with antibacterial activity from the cyanobacterium nostoc commune. J. Nat. Prod. 1999, 62, 502-503. [CrossRef] [PubMed]

46. Gekwick, W.H.; Reyes, S.; Alvarado, B. Two malyngamides from the caribbean cyanobacterium lyngbya majuscula. Phytochemistry 1987, 26, 1701-1704. [CrossRef]

47. Raveh, A.; Carmeli, S. Antimicrobial ambiguines from the cyanobacterium fischerella sp. Collected in israel. J. Nat. Prod. 2007, 70, 196-201. [CrossRef]

48. Ishida, K.; Murakami, M. Kasumigamide, an antialgal peptide from the cyanobacterium microcystis aeruginosa. J. Org. Chem. 2000, 65, 5898-5900. [CrossRef]

49. Luesch, H.; Harrigan, G.; Goetz, G.; Horgen, F. The cyanobacterial origin of potent anticancer agents originally isolated from sea hares. Curr. Med. Chem. 2002, 9, 1791-1806. [CrossRef]

50. Mi, Y.; Zhang, J.; He, S.; Yan, X. New peptides isolated from marine cyanobacteria, an overview over the past decade. Mar. Drugs 2017, 15, 132. [CrossRef]

51. Vijayakumar, S.; Menakha, M. Pharmaceutical applications of cyanobacteria-A review. J. Acute Med. 2015, 5, 15-23. [CrossRef]

52. Trimurtulu, G.; Ohtani, I.; Patterson, G.M.; Moore, R.E.; Corbett, T.H.; Valeriote, F.A.; Demchik, L. Total structures of cryptophycins, potent antitumor depsipeptides from the blue-green alga nostoc sp. Strain gsv 224. J. Am. Chem. Soc. 1994, 116, 4729-4737. [CrossRef]

53. Panda, D.; DeLuca, K.; Williams, D.; Jordan, M.A.; Wilson, L. Antiproliferative mechanism of action of cryptophycin-52: Kinetic stabilization of microtubule dynamics by high-affinity binding to microtubule ends. Proc. Natl. Acad. Sci. USA 1998, 95, 9313-9318. [CrossRef] [PubMed]

54. Sueyoshi, K.; Kaneda, M.; Sumimoto, S.; Oishi, S.; Fujii, N.; Suenaga, K.; Teruya, T. Odoamide, a cytotoxic cyclodepsipeptide from the marine cyanobacterium okeania sp. Tetrahedron 2016, 72, 5472-5478. [CrossRef] 
55. Leão, P.N.; Costa, M.; Ramos, V.; Pereira, A.R.; Fernandes, V.C.; Domingues, V.F.; Gerwick, W.H.; Vasconcelos, V.M.; Martins, R. Antitumor activity of hierridin b, a cyanobacterial secondary metabolite found in both filamentous and unicellular marine strains. PLOS ONE 2013, 8, e69562.

56. Abed, R.M.; Dobretsov, S.; Sudesh, K. Applications of cyanobacteria in biotechnology. J. Appl. Microbiol. 2009, 106, 1-12. [CrossRef]

57. Shishido, T.K.; Humisto, A.; Jokela, J.; Liu, L.; Wahlsten, M.; Tamrakar, A.; Fewer, D.P.; Permi, P.; Andreote, A.P.; Fiore, M.F. Antifungal compounds from cyanobacteria. Mar. Drugs 2015, 13, 2124-2140. [CrossRef]

58. MacMillan, J.B.; Molinski, T.F. Majusculoic acid, a brominated cyclopropyl fatty acid from a marine cyanobacterial mat assemblage. J. Nat. Prod. 2005, 68, 604-606. [CrossRef]

59. Sivakumar, J.; Santhanam, P. Antipathogenic activity of spirulina powder. Recent Res. Sci. Technol. 2011, 3, 158-161.

60. Clark, B.R.; Engene, N.; Teasdale, M.E.; Rowley, D.C.; Matainaho, T.; Valeriote, F.A.; Gerwick, W.H. Natural products chemistry and taxonomy of the marine cyanobacterium blennothrix cantharidosmum. J. Nat. Prod. 2008, 71, 1530-1537. [CrossRef]

61. Vining, O.B.; Medina, R.A.; Mitchell, E.A.; Videau, P.; Li, D.; Serrill, J.D.; Kelly, J.X.; Gerwick, W.H.; Proteau, P.J.; Ishmael, J.E. Depsipeptide companeramides from a panamanian marine cyanobacterium associated with the coibamide producer. J. Nat. Prod. 2015, 78, 413-420. [CrossRef]

62. Chai, Q.-Y.; Yang, Z.; Lin, H.-W.; Han, B.-N. Alkynyl-containing peptides of marine origin: A review. Mar. Drugs 2016, 14, 216. [CrossRef] [PubMed]

63. Plavšić, M.; Terzic, S.; Ahel, M.; Van Den Berg, C. Folic acid in coastal waters of the adriatic sea. Mar. Freshw. Res. 2003, 53, 1245-1252. [CrossRef]

64. Villa, F.A.; Lieske, K.; Gerwick, L. Selective myd88-dependent pathway inhibition by the cyanobacterial natural product malyngamide f acetate. Eur. J. Pharmacol. 2010, 629, 140-146. [CrossRef] [PubMed]

65. Motuhi, S.-E.; Mehiri, M.; Payri, C.; La Barre, S.; Bach, S. Marine natural products from new caledonia-A review. Mar. Drugs 2016, 14, 58. [CrossRef] [PubMed]

66. Leal, M.C.; Munro, M.H.; Blunt, J.W.; Puga, J.; Jesus, B.; Calado, R.; Rosa, R.; Madeira, C. Biogeography and biodiscovery hotspots of macroalgal marine natural products. Nat. Prod. Rep. 2013, 30, 1380-1390. [CrossRef] [PubMed]

67. Patra, J.K.; Lee, S.W.; Park, J.G.; Baek, K.H. Antioxidant and antibacterial properties of essential oil extracted from an edible seaweed undaria pinnatifida. J. Food Biochem. 2017, 41, e12278. [CrossRef]

68. Collins, K.G.; Fitzgerald, G.F.; Stanton, C.; Ross, R.P. Looking beyond the terrestrial: The potential of seaweed derived bioactives to treat non-communicable diseases. Mar. Drugs 2016, 14, 60. [CrossRef]

69. Taylor, F. Pharmacodynamic basis of herbal medicine, 2nd ed.; CRC Press: Boca Raton, FL, USA, 2006; p. 699.

70. Vera, J.; Castro, J.; Gonzalez, A.; Moenne, A. Seaweed polysaccharides and derived oligosaccharides stimulate defense responses and protection against pathogens in plants. Mar. Drugs 2011, 9, 2514-2525. [CrossRef]

71. Lee, J.-B.; Ohta, Y.; Hayashi, K.; Hayashi, T. Immunostimulating effects of a sulfated galactan from codium fragile. Carbohydr. Res. 2010, 345, 1452-1454. [CrossRef]

72. De Souza, É.T.; Pereira de Lira, D.; Cavalcanti de Queiroz, A.; Costa da Silva, D.J.; Bezerra de Aquino, A.; Campessato Mella, E.A.; Prates Lorenzo, V.; De Miranda, G.E.C.; de Araújo-Júnior, J.X.; de Oliveira Chaves, M.C. The antinociceptive and anti-inflammatory activities of caulerpin, a bisindole alkaloid isolated from seaweeds of the genus caulerpa. Mar. Drugs 2009, 7, 689-704. [CrossRef]

73. Okai, Y.; Higashi-Okai, K. Potent anti-inflammatory activity of pheophytin a derived from edible green alga, enteromorpha prolifera (sujiao-nori). Int. J. Immunopharmacol. 1997, 19, 355-358. [CrossRef]

74. Wall, M.E.; Wani, M.C.; Manikumar, G.; Taylor, H.; Hughes, T.J.; Gaetano, K.; Gerwick, W.H.; McPhail, A.T.; McPhail, D.R. Plant antimutagenic agents 7. Structure and antimutagenic properties of cymobarbatol and 4-isocymbarbatol, new cymopols from green alga (cymopolia barbata). J. Nat. Prod. 1989, 52, 1092-1099. [CrossRef] [PubMed]

75. Smit, A.J. Medicinal and pharmaceutical uses of seaweed natural products: A review. J. Appl. Phycol. 2004, 16, 245-262. [CrossRef]

76. Fischel, J.; Lemee, R.; Formento, P.; Caldani, C.; Moll, J.; Pesando, D.; Meinesz, A.; Grelier, P.; Pietra, P.; Guerriero, A. Cell growth inhibitory effects of caulerpenyne, a sesquiterpenoid from the marine algae caulerpa taxifolia. Anticancer Res. 1995, 15, 2155-2160. [PubMed] 
77. Hosokawa, M.; Miyashita, T.; Nishikawa, S.; Emi, S.; Tsukui, T.; Beppu, F.; Okada, T.; Miyashita, K. Fucoxanthin regulates adipocytokine mrna expression in white adipose tissue of diabetic/obese kk-ay mice. Arch. Biochem. Biophys. 2010, 504, 17-25. [CrossRef] [PubMed]

78. Lee, J.-B.; Koizumi, S.; Hayashi, K.; Hayashi, T. Structure of rhamnan sulfate from the green alga monostroma nitidum and its anti-herpetic effect. Carbohydr. Polym. 2010, 81, 572-577. [CrossRef]

79. Zhang, H.; Xiao, X.; Conte, M.M.; Khalil, Z.; Capon, R.J. Spiralisones a-d: Acylphloroglucinol hemiketals from an australian marine brown alga, zonaria spiralis. Org. Biomol. Chem. 2012, 10, 9671-9676. [CrossRef]

80. Choi, B.W.; Ryu, G.; Park, S.H.; Kim, E.S.; Shin, J.; Roh, S.S.; Shin, H.C.; Lee, B.H. Anticholinesterase activity of plastoquinones from sargassum sagamianum: Lead compounds for alzheimer's disease therapy. Phytother. Res. 2007, 21, 423-426. [CrossRef]

81. Rahelivao, M.; Gruner, M.; Andriamanantoanina, H.; Andriamihaja, B.; Bauer, I.; Knölker, H.-J. Red algae (rhodophyta) from the coast of madagascar: Preliminary bioactivity studies and isolation of natural products. Mar. Drugs 2015, 13, 4197-4216. [CrossRef]

82. Makkar, F.; Chakraborty, K. Previously undescribed antioxidative azocinyl morpholinone alkaloid from red seaweed gracilaria opuntia with anti-cyclooxygenase and lipoxygenase properties. Nat. Prod. Res. 2018, 32, 1150-1160. [CrossRef]

83. Ren, D.; Wood, T.K. (5z)-4-bromo-5-(bromomethylene)-3-butyl-2 (5h)-furanone reduces corrosion from desulfotomaculum orientis. Environ. Microbiol. 2004, 6, 535-540. [CrossRef] [PubMed]

84. Haefner, B. Drugs from the deep: Marine natural products as drug candidates. Drug Discov. Today 2003, 8 , 536-544. [CrossRef]

85. Hamman, M.T.; Otto, C.S.; Scheuer, P.J.; Dunbar, D.C. Kahalalides: Bioactive peptides from a marine mollusk elysia rufescens and its algal diet bryopsis sp. J. Org. Chem. 1998, 63, 4856. [CrossRef]

86. Hamed, I.; Özogul, F.; Özogul, Y.; Regenstein, J.M. Marine bioactive compounds and their health benefits: A review. Compr. Rev. Food Sci. Food Saf. 2015, 14, 446-465. [CrossRef]

87. Prajapati, V.D.; Maheriya, P.M.; Jani, G.K.; Solanki, H.K. Carrageenan: A natural seaweed polysaccharide and its applications. Carbohydr. Polym. 2014, 105, 97-112. [CrossRef] [PubMed]

88. Houck, J.; Bhayana, J.; Lee, T. The inhibition of pepsin and peptic ulcers. Gastroenterology 1960, $39,196$. [CrossRef]

89. Ahmadi, A.; Zorofchian Moghadamtousi, S.; Abubakar, S.; Zandi, K. Antiviral potential of algae polysaccharides isolated from marine sources: A review. BioMed Res. Int. 2015, 2015. [CrossRef]

90. Pushpamali, W.A.; Nikapitiya, C.; De Zoysa, M.; Whang, I.; Kim, S.J.; Lee, J. Isolation and purification of an anticoagulant from fermented red seaweed lomentaria catenata. Carbohydr. Polym. 2008, 73, 274-279. [CrossRef]

91. Deepa, S.; Bhuvana, B.; Hemamalini, S.; Janet, C.; Kumar, S. Therapeutic potential and pharmacological significance of the marine algae gracilaria corticata. Pharm. Biol. Eval. 2017, 4, 68-72.

92. Yasoda, H.N.; Chi, Z.; Zhu, K. Probiotics and sea cucumber farming. SPC Bechedemer Inf. Bull. 2006, $24,45$.

93. Kurihara, H.; Kagawa, Y.; Konno, R.; Kim, S.M.; Takahashi, K. Lipoxygenase inhibitors derived from marine macroalgae. Bioorg. Med. Chem. Lett. 2014, 24, 1383-1385. [CrossRef] [PubMed]

94. Witvrouw, M.; Este, J.; Mateu, M.; Reymen, D.; Andrei, G.; Snoeck, R.; Ikeda, S.; Pauwels, R.; Bianchini, N.V.; Desmyter, J. Activity of a sulfated polysaccharide extracted from the red seaweed aghardhiella tenera against human immunodeficiency virus and other enveloped viruses. Antivir. Chem. Chemother. 1994, 5, 297-303. [CrossRef]

95. Devi, K.P.; Suganthy, N.; Kesika, P.; Pandian, S.K. Bioprotective properties of seaweeds: In vitro evaluation of antioxidant activity and antimicrobial activity against food borne bacteria in relation to polyphenolic content. BMC Complement. Altern. Med. 2008, 8, 38. [CrossRef] [PubMed]

96. Mandal, P.; Pujol, C.A.; Carlucci, M.J.; Chattopadhyay, K.; Damonte, E.B.; Ray, B. Anti-herpetic activity of a sulfated xylomannan from scinaia hatei. Phytochemistry 2008, 69, 2193-2199. [CrossRef] [PubMed]

97. Bouhlal, R.; Haslin, C.; Chermann, J.-C.; Colliec-Jouault, S.; Sinquin, C.; Simon, G.; Cerantola, S.; Riadi, H.; Bourgougnon, N. Antiviral activities of sulfated polysaccharides isolated from sphaerococcus coronopifolius (rhodophytha, gigartinales) and boergeseniella thuyoides (rhodophyta, ceramiales). Mar. Drugs 2011, 9, 1187-1209. [CrossRef] [PubMed]

98. Serkedjieva, J. Antiviral activity of the red marine alga ceramium rubrum. Phytother. Res. 2004, 18, 480-483. [CrossRef] 
99. Heo, S.-J.; Cha, S.-H.; Lee, K.-W.; Jeon, Y.-J. Antioxidant activities of red algae from jeju island. Algae 2006, 21, 149-156. [CrossRef]

100. Nogueira, C.C.R.; de Palmer Paixão, I.C.N.; Teixeira, V.L. Antioxidant activity of natural products isolated from red seaweeds. Nat. Prod. Commun. 2014, 9, 1934578X1400900737. [CrossRef]

101. Yeh, C.-C.; Tseng, C.-N.; Yang, J.-I.; Huang, H.-W.; Fang, Y.; Tang, J.-Y.; Chang, F.-R.; Chang, H.-W. Antiproliferation and induction of apoptosis in ca9-22 oral cancer cells by ethanolic extract of gracilaria tenuistipitata. Molecules 2012, 17, 10916-10927. [CrossRef]

102. Yeh, C.-C.; Yang, J.-I.; Lee, J.-C.; Tseng, C.-N.; Chan, Y.-C.; Hseu, Y.-C.; Tang, J.-Y.; Chuang, L.-Y.; Huang, H.-W.; Chang, F.-R. Anti-proliferative effect of methanolic extract of gracilaria tenuistipitata on oral cancer cells involves apoptosis, DNA damage, and oxidative stress. BMC Complement. Alternat. Med. 2012, 12, 142. [CrossRef]

103. Smyrniotopoulos, V.; Vagias, C.; Rahman, M.M.; Gibbons, S.; Roussis, V. Structure and antibacterial activity of brominated diterpenes from the red alga sphaerococcus coronopifolius. Chem. biodivers. 2010, 7, 186-195. [CrossRef] [PubMed]

104. Pérez, M.; Falqué, E.; Domínguez, H. Antimicrobial action of compounds from marine seaweed. Mar. Drugs 2016, 14, 52. [CrossRef] [PubMed]

105. Shalaby, E. Algae as promising organisms for environment and health. Plant Signal. Behav. 2011, 6, 1338-1350. [CrossRef] [PubMed]

106. Sotokawa, T.; Noda, T.; Pi, S.; Hirama, M. A three-step synthesis of halomon. Angew. Chem. Int. Ed. 2000, 39, 3430-3432. [CrossRef]

107. Andrianasolo, E.H.; France, D.; Cornell-Kennon, S.; Gerwick, W.H. DNA methyl transferase inhibiting halogenated monoterpenes from the madagascar red marine alga portieria h ornemannii. J. Nat. Prod. 2006, 69, 576-579. [CrossRef] [PubMed]

108. Groth, I.; Grünewald, N.; Alban, S. Pharmacological profiles of animal-and nonanimal-derived sulfated polysaccharides-comparison of unfractionated heparin, the semisynthetic glucan sulfate ps3, and the sulfated polysaccharide fraction isolated from delesseria sanguinea. Glycobiology 2008, 19, 408-417. [CrossRef] [PubMed]

109. Farias, W.R.; Valente, A.-P.; Pereira, M.S.; Mourão, P.A. Structure and anticoagulant activity of sulfated galactans isolation of a unique sulfated galactan from the red algaebotryocladia occidentalis and comparison of its anticoagulant action with that of sulfated galactans from invertebrates. J. Biol. Chem. 2000, 275, 29299-29307. [CrossRef]

110. Matsuhiro, B.; Conte, A.F.; Damonte, E.B.; Kolender, A.A.; Matulewicz, M.C.; Mejías, E.G.; Pujol, C.A.; Zúñiga, E.A. Structural analysis and antiviral activity of a sulfated galactan from the red seaweed schizymenia binderi (gigartinales, rhodophyta). Carbohydr. Res. 2005, 340, 2392-2402. [CrossRef]

111. Faulkner, D.J. Marine natural products. Nat. Prod. Rep. 2001, 18, 1R-49R. [CrossRef]

112. Haugan, J.A. Algal carotenoids 54. Carotenoids of brown algae (phaeophyceae). Biochem. Syst. Ecol. 1994, 22, 31-41. [CrossRef]

113. D’Orazio, N.; Gemello, E.; Gammone, M.A.; de Girolamo, M.; Ficoneri, C.; Riccioni, G. Fucoxantin: A treasure from the sea. Mar. Drugs 2012, 10, 604-616. [CrossRef] [PubMed]

114. Piper, R. Extraordinary animals: An Encyclopedia of Curious and Unusual Animals; Greenwood Publishing Group: London, UK, 2007; p. 320.

115. Zhang, H.; Pang, Z.; Han, C. Undaria pinnatifida (wakame): A seaweed with pharmacological properties. Sci. Int. 2014, 2, 32-36. [CrossRef]

116. Khan, M.N.A.; Cho, J.-Y.; Lee, M.-C.; Kang, J.-Y.; Park, N.G.; Fujii, H.; Hong, Y.-K. Isolation of two anti-inflammatory and one pro-inflammatory polyunsaturated fatty acids from the brown seaweed undaria pinnatifida. J. Agric. Food Chem. 2007, 55, 6984-6988. [CrossRef] [PubMed]

117. Park, M.-K.; Jung, U.; Roh, C. Fucoidan from marine brown algae inhibits lipid accumulation. Mar. Drugs 2011, 9, 1359-1367. [CrossRef] [PubMed]

118. Spavieri, J.; Allmendinger, A.; Kaiser, M.; Casey, R.; Hingley-Wilson, S.; Lalvani, A.; Guiry, M.D.; Blunden, G.; Tasdemir, D. Antimycobacterial, antiprotozoal and cytotoxic potential of twenty-one brown algae (phaeophyceae) from british and irish waters. Phytother. Res. 2010, 24, 1724-1729. [CrossRef] [PubMed] 
119. Lutay, N.; Nilsson, I.; Wadström, T.; Ljungh, Å. Effect of heparin, fucoidan and other polysaccharides on adhesion of enterohepatic helicobacter species to murine macrophages. Appl. Biochem. Biotechnol. 2011, 164, 1-9. [CrossRef] [PubMed]

120. Ale, M.T.; Maruyama, H.; Tamauchi, H.; Mikkelsen, J.D.; Meyer, A.S. Fucoidan from sargassum sp. And fucus vesiculosus reduces cell viability of lung carcinoma and melanoma cells in vitro and activates natural killer cells in mice in vivo. Int. J. Biol. Macromol. 2011, 49, 331-336. [CrossRef]

121. Salgado, L.T.; Tomazetto, R.; Cinelli, L.P.; Farina, M.; Amado Filho, G.M. The influence of brown algae alginates on phenolic compounds capability of ultraviolet radiation absorption in vitro. Braz. J. Oceanogr. 2007, 55, 145-154. [CrossRef]

122. Kang, M.-C.; Wijesinghe, W.; Lee, S.-H.; Kang, S.-M.; Ko, S.-C.; Yang, X.; Kang, N.; Jeon, B.-T.; Kim, J.; Lee, D.-H. Dieckol isolated from brown seaweed ecklonia cava attenuates type iidiabetes in $\mathrm{db} / \mathrm{db}$ mouse model. Food Chem. Toxicol. 2013, 53, 294-298. [CrossRef] [PubMed]

123. Moubayed, N.M.; Al Houri, H.J.; Al Khulaifi, M.M.; Al Farraj, D.A. Antimicrobial, antioxidant properties and chemical composition of seaweeds collected from saudi arabia (red sea and arabian gulf). Saudi J. Biol. Sci. 2017, 24, 162-169. [CrossRef] [PubMed]

124. Rengasamy, K.R.; Aderogba, M.A.; Amoo, S.O.; Stirk, W.A.; Van Staden, J. Potential antiradical and alpha-glucosidase inhibitors from ecklonia maxima (osbeck) papenfuss. Food Chem. 2013, 141, 1412-1415. [CrossRef] [PubMed]

125. Puspita, M.; Deniel, M.; Widowati, I.; Radjasa, O.; Douzenel, P.; Bedoux, G.; Bourgougnon, N. Antioxidant and antibacterial activity of solid-liquid and enzyme-assisted extraction of phenolic compound from three species of tropical sargassum. In IOP Conference Series: Earth and Environmental Science; IOP Publishing Ltd.: Bali, Indonesia, 2017; p. 012057.

126. Khan, A.; Uddin, N.; Khaliq, S.; Nawaz, S.; Rasheed, M.; Dar, A.; Hanif, M.; Siddiqui, P.J.A. Brown seaweeds administration generate psychotherapeutic response associated with brain norepinephrine modulation in rats. J. Pharm. Phytother. 2017, 9, 11-18.

127. Grosso, C.; Andrade, P.; Valentao, P.; Mouga, T.; Jäger, A. Seaweeds: New source of mao-a inhibiting compounds. Planta Med. 2011, 77, PM69. [CrossRef]

128. Jacobs, R.S.; Culver, P.; Langdon, R.; O’Brien, T.; White, S. Some pharmacological observations on marine natural products. Tetrahedron 1985, 41, 981-984. [CrossRef]

129. Nishibori, N.; Itoh, M.; Kashiwagi, M.; Arimochi, H.; Morita, K. In vitro cytotoxic effect of ethanol extract prepared from sporophyll of undaria pinnatifida on human colorectal cancer cells. Phytother. Res. 2012, 26, 191-196. [CrossRef] [PubMed]

130. Dorta, E.; Díaz-Marrero, A.R.; Cueto, M.; Darias, J. On the relative stereochemistry of atomaric acid and related compounds. Tetrahedron 2003, 59, 2059-2062. [CrossRef]

131. Kalimuthu, S.; Kim, S.-K. Fucoidan, a sulfated polysaccharides from brown algae as therapeutic target for cancer. In Handbook of Anticancer Drugs from Marine Origin; Springer: Cham, Switzerland, 2015; pp. 145-164.

132. Hu, X.; Jiang, X.; Hwang, H.; Liu, S.; Guan, H. Antitumour activities of alginate-derived oligosaccharides and their sulphated substitution derivatives. Eur. J. Phycol. 2004, 39, 67-71. [CrossRef]

133. Ponnan, A.; Ramu, K.; Marudhamuthu, M.; Marimuthu, R.; Siva, K.; Kadarkarai, M. Antibacterial, antioxidant and anticancer properties of turbinaria conoides (j. Agardh) kuetz. Clin. Phytosci. 2017, 3, 5. [CrossRef]

134. Kim, E.J.; Park, S.Y.; Lee, J.-Y.; Park, J.H.Y. Fucoidan present in brown algae induces apoptosis of human colon cancer cells. BMC Gastroenterol. 2010, 10, 96. [CrossRef]

135. Fukuyama, Y.; Kodama, M.; Miura, I.; Kinzyo, Z.; Mori, H.; Nakayama, Y.; Takahashi, M. Anti-plasmin inhibitor. Vi.: Structure of phlorofucofuroeckol a, a novel phlorotannin with both dibenzo-1, 4-dioxin and dibenzofuran elements, from ecklonia kurome okamura. Chem. Pharmaceut. Bull. 1990, 38, 133-135. [CrossRef] [PubMed]

136. Liu, F.; Wang, J.; Chang, A.K.; Liu, B.; Yang, L.; Li, Q.; Wang, P.; Zou, X. Fucoidan extract derived from undaria pinnatifida inhibits angiogenesis by human umbilical vein endothelial cells. Phytomedicine 2012, 19, 797-803. [CrossRef] [PubMed]

137. Matsubara, K.; Xue, C.; Zhao, X.; Mori, M.; Sugawara, T.; Hirata, T. Effects of middle molecular weight fucoidans on in vitro and ex vivo angiogenesis of endothelial cells. Int. J. Mol. Med. 2005, 15, 695-699. [CrossRef] [PubMed] 
138. Cumashi, A.; Ushakova, N.A.; Preobrazhenskaya, M.E.; D'incecco, A.; Piccoli, A.; Totani, L.; Tinari, N.; Morozevich, G.E.; Berman, A.E.; Bilan, M.I. A comparative study of the anti-inflammatory, anticoagulant, antiangiogenic, and antiadhesive activities of nine different fucoidans from brown seaweeds. Glycobiology 2007, 17, 541-552. [CrossRef] [PubMed]

139. Kwak, K.-W.; Cho, K.-S.; Hahn, O.-J.; Lee, K.-H.; Lee, B.-Y.; Ko, J.-J.; Chung, K.-H. Biological effects of fucoidan isolated from fucus vesiculosus on thrombosis and vascular cells. Korean J. Hematol. 2010, 45, 51-57. [CrossRef] [PubMed]

140. Ahn, M.-J.; Yoon, K.-D.; Min, S.-Y.; Lee, J.S.; Kim, J.H.; Kim, T.G.; Kim, S.H.; Kim, N.-G.; Huh, H.; Kim, J. Inhibition of hiv-1 reverse transcriptase and protease by phlorotannins from the brown alga ecklonia cava. Biol. Pharmaceut. Bull. 2004, 27, 544-547. [CrossRef] [PubMed]

141. Hayashi, K.; Nakano, T.; Hashimoto, M.; Kanekiyo, K.; Hayashi, T. Defensive effects of a fucoidan from brown alga undaria pinnatifida against herpes simplex virus infection. Int. Immunopharmacol. 2008, 8, 109-116. [CrossRef] [PubMed]

142. Queiroz, K.; Medeiros, V.; Queiroz, L.; Abreu, L.; Rocha, H.; Ferreira, C.; Juca, M.; Aoyama, H.; Leite, E. Inhibition of reverse transcriptase activity of hiv by polysaccharides of brown algae. Biomed. Pharmacother. 2008, 62, 303-307. [CrossRef] [PubMed]

143. Béress, A.; Wassermann, O.; Bruhn, T.; Béress, L.; Kraiselburd, E.N.; Gonazalez, L.V.; de Motta, G.E.; Chavez, P.J. A new procedure for the isolation of anti-hiv compounds (polysaccharides and polyphenols) from the marine alga fucus vesiculosus. J. Nat. Prod. 1996, 59, 552. [CrossRef]

144. Dos Santos, V.A.; Leite, K.M.; da Costa Siqueira, M.; Regasini, L.O.; Martinez, I.; Nogueira, C.T.; Galuppo, M.K.; Stolf, B.S.; Pereira, A.M.S.; Cicarelli, R. Antiprotozoal activity of quinonemethide triterpenes from maytenus ilicifolia (celastraceae). Molecules 2013, 18, 1053-1062. [CrossRef]

145. Nara, T.; Kamei, Y.; Tsubouchi, A.; Annoura, T.; Hirota, K.; Iizumi, K.; Dohmoto, Y.; Ono, T.; Aoki, T. Inhibitory action of marine algae extracts on the trypanosoma cruzi dihydroorotate dehydrogenase activity and on the protozoan growth in mammalian cells. Parasitol. Int. 2005, 54, 59-64. [CrossRef] [PubMed]

146. Soares, D.C.; Calegari-Silva, T.C.; Lopes, U.G.; Teixeira, V.L.; de Palmer Paixão, I.C.; Cirne-Santos, C.; Bou-Habib, D.C.; Saraiva, E.M. Dolabelladienetriol, a compound from dictyota pfaffii algae, inhibits the infection by leishmania amazonensis. PLoS Negl. Trop. Dis. 2012, 6, e1787. [CrossRef] [PubMed]

147. Gallé, J.-B.; Attioua, B.; Kaiser, M.; Rusig, A.-M.; Lobstein, A.; Vonthron-Sénécheau, C. Eleganolone, a diterpene from the french marine alga bifurcaria bifurcata inhibits growth of the human pathogens trypanosoma brucei and plasmodium falciparum. Mar. Drugs 2013, 11, 599-610. [CrossRef] [PubMed]

148. Cho, M.; Lee, H.-S.; Kang, I.-J.; Won, M.-H.; You, S. Antioxidant properties of extract and fractions from enteromorpha prolifera, a type of green seaweed. Food Chem. 2011, 127, 999-1006. [CrossRef] [PubMed]

149. Lahaye, M.; Robic, A. Structure and functional properties of ulvan, a polysaccharide from green seaweeds. Biomacromolecules 2007, 8, 1765-1774. [CrossRef] [PubMed]

150. Qi, H.; Huang, L.; Liu, X.; Liu, D.; Zhang, Q.; Liu, S. Antihyperlipidemic activity of high sulfate content derivative of polysaccharide extracted from ulva pertusa (chlorophyta). Carbohydr. Polym. 2012, 87, 1637-1640. [CrossRef]

151. Hickey, R.M. Extraction and characterization of bioactive carbohydrates with health benefits from marine resources: Macro-and microalgae, cyanobacteria, and invertebrates. In Marine Bioactive Compounds; Springer: Boston, MA, USA, 2012; pp. 159-172.

152. Pengzhan, Y.; Quanbin, Z.; Ning, L.; Zuhong, X.; Yanmei, W.; Zhi'en, L. Polysaccharides from ulva pertusa (chlorophyta) and preliminary studies on their antihyperlipidemia activity. J. Appl. phYcol. 2003, 15, $21-27$. [CrossRef]

153. Tabarsa, M.; Lee, S.-J.; You, S. Structural analysis of immunostimulating sulfated polysaccharides from ulva pertusa. Carbohydr. Res. 2012, 361, 141-147. [CrossRef] [PubMed]

154. Celikler, S.; Tas, S.; Vatan, O.; Ziyanok-Ayvalik, S.; Yildiz, G.; Bilaloglu, R. Anti-hyperglycemic and antigenotoxic potential of ulva rigida ethanolic extract in the experimental diabetes mellitus. Food Chem. Toxicol. 2009, 47, 1837-1840. [CrossRef] [PubMed]

155. Sunilson, J.A.J.; Suraj, R.; Anandarajagopal, K.; Rejitha, G.; Vignesh, M.; Promwichit, P. Preliminary phytochemical analysis, elemental determination and antibacterial screening of codium decorticatum-A marine green algae. Int. J. Biol. Chem. 2009, 3, 84-89. 
156. Khan, M.N.; Choi, J.S.; Lee, M.C.; Kim, E.; Nam, T.J.; Fujii, H.; Hong, Y.K. Anti-inflammatory activities of methanol extracts from various seaweed species. J. Environ. Biol. 2008, 29, 465-469. [PubMed]

157. Lee, J.-B.; Hayashi, K.; Maeda, M.; Hayashi, T. Antiherpetic activities of sulfated polysaccharides from green algae. Planta Med. 2004, 70, 813-817. [CrossRef] [PubMed]

158. Sato, Y.; Hirayama, M.; Morimoto, K.; Yamamoto, N.; Okuyama, S.; Hori, K. High mannose-binding lectin with preference for the cluster of $\alpha 1-2$-mannose from the green alga boodlea coacta is a potent entry inhibitor of hiv-1 and influenza viruses. J. Biol. Chem. 2011, 286, 19446-19458. [CrossRef] [PubMed]

159. Wang, R.; Paul, V.J.; Luesch, H. Seaweed extracts and unsaturated fatty acid constituents from the green alga ulva lactuca as activators of the cytoprotective nrf2-are pathway. Free Rad. Biol. Med. 2013, 57, 141-153. [CrossRef] [PubMed]

160. Singh, R.; Parihar, P.; Singh, M.; Bajguz, A.; Kumar, J.; Singh, S.; Singh, V.P.; Prasad, S.M. Uncovering potential applications of cyanobacteria and algal metabolites in biology, agriculture and medicine: Current status and future prospects. Front. Microbiol. 2017, 8. [CrossRef] [PubMed]

161. Bhagavathy, S.; Sumathi, P.; Madhushree, M. Antimutagenic assay of carotenoids from green algae chlorococcum humicola using salmonella typhimurium ta98, ta100 and ta102. Asian Pacif. J. Trop. Dis. 2011, 1, 308-316. [CrossRef]

162. Ganesan, P.; Noda, K.; Manabe, Y.; Ohkubo, T.; Tanaka, Y.; Maoka, T.; Sugawara, T.; Hirata, T. Siphonaxanthin, a marine carotenoid from green algae, effectively induces apoptosis in human leukemia (hl-60) cells. Biochim. Biophys. Acta (BBA)-Gen. Subj. 2011, 1810, 497-503. [CrossRef] [PubMed]

163. Ganesan, P.; Matsubara, K.; Ohkubo, T.; Tanaka, Y.; Noda, K.; Sugawara, T.; Hirata, T. Anti-angiogenic effect of siphonaxanthin from green alga, codium fragile. Phytomedicine 2010, 17, 1140-1144. [CrossRef] [PubMed]

164. Selvin, J.; Lipton, A.P. Biopotentials of ulva fasciata and hypnea musciformis collected from the peninsular coast of india. J. Mar. Sci. Technol. 2004, 12, 1-6.

165. Yuvaraj, N.; Kanmani, P.; Satishkumar, R.; Paari, K.; Pattukumar, V.; Arul, V. Extraction, purification and partial characterization of cladophora glomerata against multidrug resistant human pathogen acinetobacter baumannii and fish pathogens. World J. Fish Mar. Sci. 2011, 3, 51-57.

166. Smyrniotopoulos, V.; Abatis, D.; Tziveleka, L.-A.; Tsitsimpikou, C.; Roussis, V.; Loukis, A.; Vagias, C. Acetylene sesquiterpenoid esters from the green alga caulerpa prolifera. J. Nat. Prod. 2003, 66, 21-24. [CrossRef] [PubMed]

167. Deacon-Smith, R.; Lee-Potter, J.; Rogers, D. Anticoagulant activity in extracts of british marine algae. Bot. Mar. 1985, 28, 333-338. [CrossRef]

168. Matsubara, K.; Matsuura, Y.; Hori, K.; Miyazawa, K. An anticoagulant proteoglycan from the marine green alga, codium pugniformis. J. Appl. Phycol. 2000, 12, 9-14. [CrossRef]

169. Maeda, M.; Uehara, T.; Harada, N.; Sekiguchi, M.; Hiraoka, A. Heparinoid-active sulphated polysaccharides frommonostroma nitidum and their distribution in the chlorophyta. Phytochemistry 1991, 30, 3611-3614. [CrossRef]

170. Synytsya, A.; Choi, D.J.; Pohl, R.; Na, Y.S.; Capek, P.; Lattová, E.; Taubner, T.; Choi, J.W.; Lee, C.W.; Park, J.K. Structural features and anti-coagulant activity of the sulphated polysaccharide sps-cf from a green alga capsosiphon fulvescens. Mar. Biotechnol. 2015, 17, 718-735. [CrossRef]

171. Patel, S. Therapeutic importance of sulfated polysaccharides from seaweeds: Updating the recent findings. 3 Biotech 2012, 2, 171-185. [CrossRef]

172. Watanabe, Y.; Naganuma, T.; Ogawa, T.; Muramoto, K. Lectins of marine origin and their clinical applications. In Antitumor Potential and Other Emerging Medicinal Properties of Natural Compounds; Springer: New York, NY, USA, 2013; pp. 33-54.

(C) 2019 by the authors. Licensee MDPI, Basel, Switzerland. This article is an open access article distributed under the terms and conditions of the Creative Commons Attribution (CC BY) license (http://creativecommons.org/licenses/by/4.0/). 